\title{
Will They Sing the Same Tune? Measuring Convergence in the new European System of Financial Supervisors
}

Donato Masciandaro, Maria J. Nieto and

Marc Quintyn 


\title{
IMF Working Paper
}

\author{
Will they Sing the Same Tune? \\ Measuring Convergence in the new European System of Financial Supervisors
}

\section{Prepared by Donato Masciandaro, Maria J. Nieto and Marc Quintyn ${ }^{1}$}

July 2009

\begin{abstract}
This Working Paper should not be reported as representing the views of the IMF.

The views expressed in this Working Paper are those of the author(s) and do not necessarily represent those of the IMF or IMF policy. Working Papers describe research in progress by the author(s) and are published to elicit comments and to further debate.
\end{abstract}

In June 2009 a new financial supervisory framework for the European Union (EU) was endorsed, consisting of a macro- and a micro-prudential pillar. The latter is composed of a Steering Committee, a supranational layer and a network of national supervisory authorities at the bottom, de facto establishing a complex multiple principals-multiple agents network. This paper focuses on the network of national agencies. Starting from an analysis of supervisory architectures and governance arrangements, we assess to what extent lack of convergence could undermine efficient and effective supervision. The main conclusion is that harmonization of governance arrangements towards best practice would better align supervisors' incentive structures and, hence, be beneficial for the quality of supervision.

JEL Classification Numbers: G28, G38, E58.

Keywords: Financial supervision, EU integration, supervisory architectures and governance

Author’s E-Mail Address: mquintyn@imf.org; donato.masciandaro@unibocconi.it; maria.nieto@bde.es

\footnotetext{
${ }^{1}$ Masciandaro is professor at the Department of Economics, Bocconi University, Milan. He gratefully acknowledges the support of the Paolo Baffi Centre. Nieto is Advisor at the Bank of Spain. The views expressed in this paper do not necessarily represent those of the Bank of Spain. The authors would like to thank, without implication, Rosaria Vega Pansini for skillful research assistance and Martin Čihàk, Sylvester Eijffinger, Wim Fonteyne, Tomislav Galac, Daniel Hardy, Fabio Recine, Jan Willem van der Vossen and participants at the Finlawmetrics 2009 Conference (Milan, June 18-19, 2009) for helpful comments and suggestions.
} 
I. Introduction 3

II. A European Supervisory Structure is Born. .5

III. Review of Supervisory Architectures ....................................................................6

A. Closer analysis of the EU supervisory landscape ..........................................

B. Potential policy implications of polarization ................................................ 10

IV. Convergence in Supervisory Governance ................................................................... 11

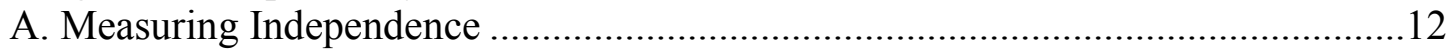

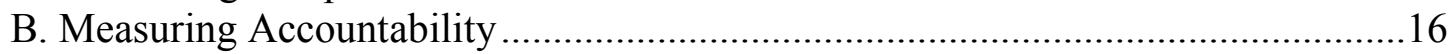

C. Is There Governance Convergence Within the EU? .........................................19

V. Conclusions and Policy Considerations ....................................................................21

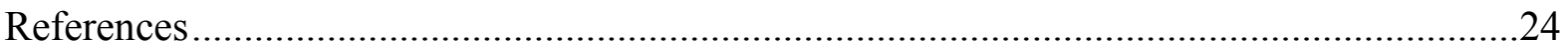

Figures

Figure 1 Financial Supervisory Regimes: number of reforms per year (1998-2008).............28

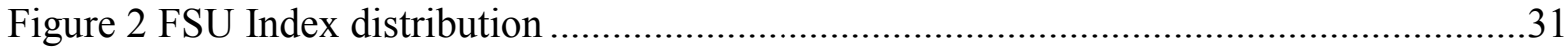

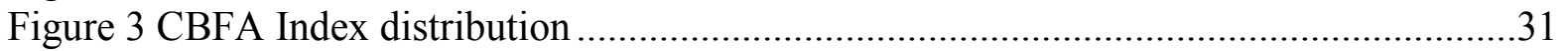

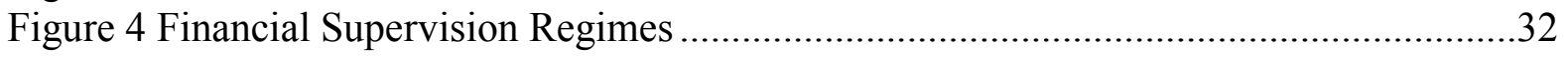

Figure 5 Institutional Independence: Cross-country convergence......................................33

Figure 6 Regulatory \& Supervisory Independence: Cross-country convergence....................33

Figure 7 Budgetary independence: Cross-country convergence ............................................34

Figure 8 Political accountability: Cross-country convergence .............................................34

Figure 9 Judiciary accountability: Cross-country convergence ...........................................35

Figure 10 Transparency: Cross-country convergence ...................................................35

Figure 11 Total independence: Cross-country convergence..........................................36

Figure 12 Overall accountability Cross-country convergence ...........................................36

Figure 13 Independence and Accountability: scatter-plot ..............................................37

Figure 14 Independence and Accountability inside and outside the Central Bank ................38

Figure 14A: Independence Indices inside and outside the Central Bank ..............................38

Figure 14B: Accountability Indices inside and outside the Central Bank ............................39

Tables

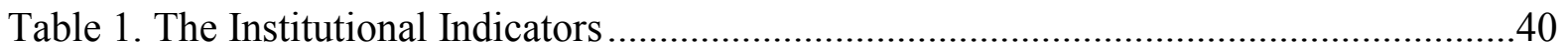

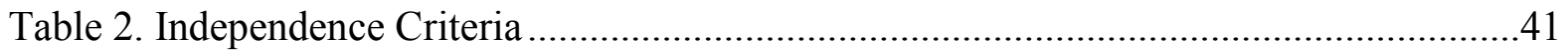

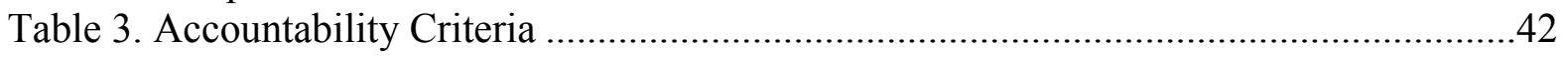

Annexes

Annex - The European Framework for Safeguarding Financial Stability .............................43 


\section{INTRODUCTION}

The development of a single financial market has been a long-term objective of the European Union (EU) and the achievement of this objective received a significant impetus with the introduction of the Euro, which has acted in many ways as a catalyst for financial integration. Soon after the establishment of the European Central Bank (ECB), a debate emerged about the desirable structure of financial supervision in this single financial market. In many circles it was indeed felt that, in order to support EU financial integration and preserve financial sector soundness, a substantive degree of coordination of regulatory and supervisory actions was needed.

For a long time, the debate remained dominated by divergences in academic and policy circles between, on the one hand, proponents of light forms of coordination among national supervisors, and on the other, those in favor of more centralized approaches. ${ }^{2}$ Meanwhile, some initiatives in support of more regulatory and supervisory coordination among member states saw the light of day. The most important ones were: (i) on the regulatory side, the establishment of the Lamfalussy framework, an elaborate structure aiming at speeding up the legislative process governing the European financial system, delivering more uniform and better technical regulation, and facilitating supervisory convergence in support of financial integration and stability; and (ii) on the supervisory side, the establishment of supervisory colleges in charge of monitoring large cross-border groups. ${ }^{3}$

However, as is often the case, it takes a crisis to reform. The impact of the current financial crisis on EU members introduced a sense of urgency to the coordination/centralization debate. Indeed, two issues for regulatory and supervisory reform that have been gaining worldwide acceptance in the wake of the crisis are: (i) the expansion of the cross-institutional and crossborder scope for regulation while safeguarding constructive diversity; and (ii) the need for putting in place mechanisms for effective and coordinated supervisory actions (Sacasa, 2008). With 46 banking groups with significant holdings of cross-border assets and liabilities active on the EU's territory at end 2007, the relevance of these recommendations is great indeed. These cross-border banks operate in a multi-jurisdictional environment and do need to interact with multiple national supervisors. Against this background, the consensus has been growing that the efficiency and effectiveness of existing frameworks for banking regulation and supervision needs to be (re)assessed.

In October of 2008, the European Commission mandated a group of experts, under the chairmanship of Jacques de Larosière to formulate recommendations on the future of European

\footnotetext{
${ }^{2}$ See CEPS (2008) and Fonteyne and Van der Vossen (2007) for overviews. Kremers et al. (2003) provides a good overview of the debate in the earlier years. Individual contributions include Nieto and Peñalosa, (2004) and Lastra (2006) on the need to harmonize regulatory frameworks; Prati and Schinasi (1999) and Goodhart (2000) on the establishment of integrated financial oversight; and Holthausen and Ronde (2005) and Mayes, Nieto and Wall (2008) on incentives for cooperation among national supervisors.

${ }^{3}$ For overviews, see CEPS (2008) and Fonteyne and Van der Vossen (2007).
} 
financial regulation and supervision. The group presented its report to the Commission in early Spring of 2009. ${ }^{4}$ Since then, developments at the policy level have gained momentum. On May 27, 2009 the European Commission published its proposal for the structure of European financial supervision (based on the de Larosiere recommendations) which was adopted by ECOFIN on June 9 and by the European Council on June 18-19, 2009. 56

The adopted structure consists of a macro-prudential supervisory framework centered around the European Systemic Risk Council (ESRC) and a micro-prudential supervisory framework, the European System of Financial Supervisors (ESFS), consisting of a steering committee, three sectoral European Supervisory Authorities (ESA) and the network of national supervisors (see Annex).

This paper focuses on the micro-prudential framework and is motivated by the finding that this relatively complex three-layered framework for micro-prudential supervision is composed, at the bottom layer, of a large group of a very heterogeneous set of national supervisory architectures (47 agencies for 27 countries), with a wide variety of governance arrangements, supervisory cultures and regulatory frameworks. Thus far, these features, and their implications for the working of the ESFS, have not really been the topic of any discussion (or concern) in the reform debate. ${ }^{78}$

\footnotetext{
${ }^{4}$ The de Larosière Report (2009).

${ }^{5}$ Commission of the European Communities (2009), and Council of the European Union (2009).

${ }^{6}$ In the months leading up to the recent decision, other proposals were floated as well. See for instance Wirtschaftswoche (2009) where ECB vice-president Papademos suggested that the ECB be in charge of the supervision of the large banks with cross-border operations. Hardy (2009) suggested the adoption of a "European mandate" for national supervisors as a first step towards more coordination. Note that this proposal is not necessarily incompatible with the adopted framework. Defining such a mandate could actually be a stepping stone to make the new structure more incentive-compatible (see later).

${ }^{7}$ The de Larosière Report (2009, page 53) recommends that “....organization, competences and independence of national supervisory authorities..." be evaluated, which should lead to concrete recommendations for improvement. On some occasions, the European authorities (Commission and ECB) have issued opinions on planned reforms in regulatory frameworks in member countries. Europe-specific studies that compared regulatory governance arrangements among members based on finding of IMF-World Bank Financial Sector Assessments Programs (FSAP) include Čihàk and Tieman, 2007 and 2008, and Čihàk and Fonteyne, 2009.

${ }^{8}$ As a short aside, a preliminary comparison with the process of establishing the ECB and the ESCB in the 1990s illustrates some of the more complex issues that policymakers will face when making the ESFS operational. First, some governance reforms in the national central banks were put forward as a prerequisite for joining the Eurosystem. This convergence process was facilitated by the fact that central banks have always been more similar than supervisory agencies in terms of governance and mandates. In addition, the main task of the national central banks - formulation and implementation of monetary policy - was centralized in the ECB, whereas in the case of the ESFS the national authorities retain (at least in the foreseeable future) all their powers and responsibilities.
} 
So, this paper intends to fill this void in our understanding of the potential implications of heterogeneous supervisory architectures and governance arrangements for the quality of future EU financial regulation and supervision. Starting from an analysis of the current landscape of supervisory architectures and governance practices of the main supervisor (mainly banking supervisor) in each country, we identify those areas where lack of cross-country convergence could lead to failures in providing national supervisors the right incentives to cooperate across borders, and hence, could undermine the efficiency and effectiveness of EU supervision. We finish by formulating some recommendations to address these issues.

Following a brief overview in the next section of the main features of the European supervisory structure endorsed by the European Council, we devote section III to an analysis of the current European landscape of supervisory architectures. In line with the suggestions of the new research in the field, we analyze both the overall architecture and the role of the central bank therein. This review will (i) help us in detecting preferences among the 27 EU countries regarding their supervisory architectures, and (ii) allow us to make an assessment of some of the issues that could stand in the way of efficient and effective cooperation at the European level. Section IV will analyze the degree of similarity in the governance of national financial supervisory authorities. We focus on two main dimensions of supervisory governance, independence and accountability. It will be pointed out that some differences in governance arrangements at the national level could potentially have a negative impact on European supervisory coordination - and thus European financial stability. This leads us to argue that (i) harmonization of governance principles towards the highest levels is essential in order to maximize effectiveness and efficiency of the new supervisory structure, and (ii) that such best practices should serve as a reference for the design of the governance arrangements of the supranational structures that will be put in place.

\section{A European SUPERVISORY STRUCTURE IS BORN}

Following years of debate and slow action on this front, European supervisory reform got the centerstage since the middle of 2008. Particularly in the course of 2008 (the UK was severely hit in 2007), the financial crisis hit the EU financial system in all its layers and lay bare the weaknesses in the regulatory and supervisory coordination framework. In response to these events, the EU Commission mandated in late 2008 a group of experts under the chairmanship of Jacques de Larosière to present an analysis of the causes of the financial crisis as well as recommendations for supervisory reform on Europe.

The group presented its report in early Spring of 2009. The report proposed a strengthening of the Level 3 committees of the Lamfalussy framework in a first stage (Recommendation 20). In a second stage an integrated European System of Financial Supervisors (ESFS) should be established (Recommendation 21). At a later stage, only two authorities would emerge: one for banking and insurance supervision and any other issue relevant for financial stability, and the other for conduct of business and market issues across sectors (Recommendation 22).

The proposal by the Commission (European Commission, 2009) in fact collapses stages 1 and 2 for micro-prudential supervision, and establishes a second pillar for macro-prudential supervision (annex). The central body of the latter is the ESRC. For micro-prudential supervision, the ESFS is a three-layered structure, with a Steering Committee, three European 
Supervisory Authorities (ESA) and the national supervisory agencies at the bottom layer. The three ESA emanate from the existing Level-3 authorities in the Lamfalussy framework. In line with the practice in this framework, they have sectoral responsibilities: the European Banking Authority (EBA), the European Insurance and Occupational Pension Authority (EIOPA), and the European Securities Authority (ESA). A complex set arrows indicates all the lines of communication between the two pillars as well as with the national authorities and the European authorities. The proposal of the Commission received the full support of ECOFIN on June 9 and the European Council adopted it as the European Supervisory Framework for the future during the June $18-19$ Summit.

In the remainder of the paper we focus on the ESFS, the microprudential framework. The framework, consisting of three sectoral authorities at the supranational level, belongs to the category of the traditional, or silo, approach to supervision (see next section). The Commission (section 4.3. on page 12) recognizes in one paragraph that many member countries have different architectures, but states that at the European level, this silo-approach was the most evident one (in the name of continuity, given the Lamfalussy framework).

The document remains vague with respect to the governance arrangements for the three new authorities. These need to be further elaborated in specific enabling legislation. The document states that the three authorities (ESA) should (i) be independent from the political world; they should, among others, have budgetary independence; (ii) have accountability arrangements toward the European institutions (Commission, Parliament and Court); (iii) adhere to high transparency standards; and (iv) also liaise with all stakeholders, notably consumers. The document also foresees wide-ranging powers vis-à-vis the national supervisory authorities to enforce harmonization of the regulatory framework and to correct non compliance by national supervisors. They should also play a role in harmonizing supervisory cultures among the latter. .

While many of these arrangements and powers need to be further defined and specified, and more importantly, adopted by the European political authorities, it is clear that the national supervisors are entering a multiple principals - multiple agents framework, implying that all players involved need to have an incentive-compatible governance framework in order to make this supervisory network operational, efficient and effective. This network becomes even more complex if the lines of communication with the macro-prudential pillar are taken into account. ${ }^{9}$ This short overview sets the stage for our analysis of national supervisory architectures and governance arrangements in the next sections.

\section{REVIEW OF SUPERVISORY ARCHITECTURES ${ }^{10}$}

In recent years we have witnessed a profound change in the design of the institutions responsible for supervising financial markets and banks. The landscape of financial supervision

\footnotetext{
${ }^{9}$ See e.g. Bini Smaghi (2009).

${ }^{10}$ This section draws on Masciandaro, Nieto and Quintyn (2009).
} 
has been going through a deep (r)evolution on all fronts, and many countries have undertaken important changes in their overall architecture, redefining who is responsible for what. Only 15 years ago, the issue of financial supervisory architecture was considered irrelevant. The fact that only banking systems were subject to robust supervision kept several of the current organizational questions in the sphere of irrelevance. In such a context, the supervisory design was either considered deterministic (i.e., an exogenous variable), or accidental (i.e., a completely random variable). ${ }^{11}$ Since then, financial market development, resulting in the growing importance of insurance, securities and pension fund sectors, has made supervision of a growing number of non-bank financial intermediaries, as well as the investor protection dimension of supervision, highly relevant.

As a result of these changes, financial supervisory architectures are now less uniform than in the past. In some countries the architecture still reflects the classic sectoral model, with separate supervisors for banking, securities and insurance (e.g., France, Spain and Italy). ${ }^{12}$ This model dominated until the end of the '90s (Figure 1A, sectoral model in yellow). However, an increasing number of countries have shown a trend towards consolidation of the supervisory responsibilities (Figure 1B), which has resulted in the establishment of unified supervisors in a number of countries (e.g., UK and Germany) (dark green in the Figure 1B), which are different from the national central banks, while in a few cases (e.g., Czech Republic, Ireland and Slovakia) (light green in the same Figure) the central bank emerged as the unified supervisor. Furthermore Figure 1B also shows that one country-the Netherlands-adopted the so-called objectives-based (peaks) model (grey in the Figure).

The dynamic character of these reforms is highlighted by the fact that the present financial crisis is leading to a reassessment of the recent reforms (e.g., Austria in 2008, the debate in the United Kingdom following the Northern Rock debacle as well as a reconsideration of the latest reforms in Germany and Belgium), or has opened the debate in those countries that stayed out of the previous round of reforms (most prominently the United States).

The model of supervisory architecture and its degree of consolidation are two distinctive dimensions of the reform, although they can be highly correlated. In fact the same model of financial supervision can be designed with different degrees of supervisory consolidation. The single supervisory model, where the supervision of banking, securities and insurance markets is completely integrated, is based on just one control authority; but some powers (i.e., information gathering) can be shared with other authorities (typically the central bank). ${ }^{13}$ In the (classic)

\footnotetext{
${ }^{11}$ For an historical perspective, see the discussions in Goodhart (2007) and Capie (2007).

12 Political authorities in Italy and Spain have recently expressed their intention to reorganize their supervisory architectures In Italy, the Parliament discussed in 2005 the "hybrid" supervisory institutional setting, introduced a marginal reform of the antitrust responsibilities, reduced central bank involvement in supervision and shortened the Governor's term of office. In Spain, the government has announced its intention to reform the architecture of financial supervision separating financial stability and business conduct supervision in order to build an objectives-based model (see below in the text).

${ }^{13}$ García and Nieto, 2005, Table 1 presents the central bank access to banks' prudential information.
} 
specialized (sectoral) model, with separate supervisors for banks, securities and insurance, at least three separate supervisors exist and more than one agency can supervise the same sector (as is the case in the US). The objectives-based model has one authority responsible for each objective of financial regulation (prudential supervision and business conduct). So, at least two authorities can be identified. However, some countries have identified more than two goals of supervision. As such, Australia has developed a "four peaks model." The Australian Securities and Investments Commission (ASIC) promotes the fairness in the conduct of business, the Australian Prudential Regulation Authority (APRA) is responsible for micro prudential regulation (individual institutions), the Reserve Bank cares about macro stability, while the Australian Competition and Consumer Commission is in charge of antitrust policies.

\section{A. Closer analysis of the EU supervisory landscape}

For the purposes of this study, we concentrate on the degree of consolidation of financial supervision in the individual EU countries. This degree is measured by the financial supervision unification index (FSU Index) developed in Masciandaro 2004, 2005 and 2006 (description in Table 1). The index is created through an analysis of which, and how many, authorities are empowered to supervise the three traditional sectors of financial activity: banking, securities markets and insurance. ${ }^{14}$ The qualitative information has been transformed into quantitative indicators by assigning a numerical value to each type of regime, in order to highlight the number of the agencies involved. The rationale by which the values are assigned simply considers the concept of unification of supervisory powers: the greater the degree of unification, the higher the index value. ${ }^{15}$ This gives us for each European country the level of financial supervision unification. Figure 2 shows a polarized distribution of the countries according to the FSU Index with some EU countries (9) ${ }^{16}$ showing the lowest level of consolidation of supervision (Index equal to 1), and others who have a unified supervisor (11), ${ }^{17}$ the highest level of consolidation (Index equal to 7) (8 outside and 3 inside the central bank). Note that the new EU structure shows a relatively low level of consolidation.

These different architectures are compatible with different levels of central bank involvement. Masciandaro (2006) uses the index of the central bank's involvement in financial supervision

\footnotetext{
${ }^{14}$ Sources: for all countries, official documents and websites of the central banks and the other financial authorities. The information is updated through 2006. See Table 1.

${ }^{15}$ There are five qualitative characteristics of supervisory regimes that we decided not to consider in constructing this index. Firstly, we did not consider the legal nature-public or private-of the supervisory agencies nor their relationship to the political system (degree of independence, level of accountability). Secondly, we excluded from this analysis the authority in charge of competition and market regulation. Since such an agency exists in all EU 27 countries, it was left out for the purposes of this analysis. We also did not include the agency in charge of the management of the deposit insurance schemes. In general, we consider only the three traditional sectors (banking, securities and insurance markets) that have been the subject of supervision. Finally, the financial authorities may perform different functions in the regulatory as well as in the supervisory area. However, at this first stage of the institutional analysis, we prefer to consider only the number of the agencies involved in the supervisory activities.

${ }^{16}$ Bulgaria, Cyprus, France, Greece, Lithuania, Poland, Romania, Slovenia, Spain .

${ }^{17}$ Belgium, Czech Republic, Denmark, Estonia, Hungary, Ireland, Latvia, Malta, Slovak Republic, Sweden, UK.
} 
(Central Bank as Financial Authority Index-CBFA-described in Table 1). Figure 3 shows the frequency distribution of the CBFA Index. Again a polarization holds. In the majority of EU countries (13) the central bank is not the main bank supervisor (Index equal to 1), while in just three countries (Czech Republic, Ireland and Slovakia) the central bank is monopolistic in the overall financial supervision (Index equal to 4).

Considering the FSU and the CBFA indices jointly for the EU countries, Figure 4 seems to depict a trade off between supervision unification and central bank involvement, with three outliers (Czech Republic, Ireland and Slovakia-green bubble). The two most frequently adopted regimes are polarised: on the one hand, Unified Supervisor regime ( 8 countries ${ }^{18}$-red bubble); on the other, Central Bank Dominated Multiple Supervisors regime ( 7 countries ${ }^{19}$-yellow bubble). The position of the new EU structure (black star in Figure 4) reflects the three sectoral supervisors, without ECB involvement in micro-prudential supervision.

The EU situation confirms a general finding of the recent literature: the national choices on how many agencies should be involved in supervision seem to be closely correlated with the existing institutional position of the central bank. In general, the degree of supervisory unification seems to be inversely related with the central bank's involvement in supervision. The trade-off-and the related, so called central bank fragmentation effect ${ }^{20}$ - was confirmed first using a crosscountry analysis of the reforms in the supervisory regimes (Masciandaro 2004, 2005 and 2006) and analyzing the economics of the central bank fragmentation effect (Masciandaro 2007 and 2008, Masciandaro and Quintyn 2008, Dalla Pellegrina and Masciandaro 2008). From a political economy point of view, the central bank fragmentation effect can be explained as a peculiar case of path dependence effect: the incumbent policymaker, in choosing the level of financial supervision consolidation, is influenced by the characteristics that already exist in terms of the central bank position. The policymaker's choices are viewed as a sequential process in which the institutional position of the central bank matters.

It is evident that the degree of convergence among the EU countries is low. Furthermore, it has been claimed that no "superior" model of supervision exists (see Schoenmaker 2003, and Quintyn et al., 2006, among others). Different contributions (Abrams and Taylor, 2002; Arnone and Gambini, 2007; Fleming, Lewellyn and Carmichael, 2004; Čihàk and Podpiera, 2007a, and 2007 b) claim that there are no strong theoretical arguments in favour of any particular architecture of financial supervision. Advantages and disadvantages can be associated with each model.

\footnotetext{
${ }^{18}$ Belgium, Denmark, Estonia, Hungary, Latvia, Malta, Sweden, UK.

${ }^{19}$ Bulgaria, Cyprus, Czech Republic, Greece, Lithuania, Romania, Slovenia.

${ }^{20}$ Meaning, the presence of the central bank in the supervisory field typically leads to fragmentation of supervisory responsibilities, as opposed to unification.
} 


\section{B. Potential policy implications of polarization}

Even though there is no best practice with respect to the supervisory architecture, the existence of a polarized field of supervisory architectures, as it has emerged from domestic political and economic preferences, could potentially have a number of implications for the efficiency and effectiveness of European supervisory processes. The lack of uniform national architectures is likely to render supervisory coordination among countries and with the three European authorities difficult. Several studies (e.g. Čihàk and Tieman, 2007 and 2008, based on FSAP results, and Seelig and Novoa, 2009 based on a worldwide survey) show that supervisory cultures and governance practices differ significantly among sectoral supervisors (with banking supervisors typically having the strictest supervisory culture and the most stringent governance arrangements). ${ }^{21}$ So, the wide variety of supervisory architectures, and the number of agencies on the EU territory could in the first place create hiccups in the coordination of supervisory actions and initiatives because of the multiple lines of communication.

In the second place, the wide variety of architectures goes hand in hand-almost in a one-to-one relationship — with a wide variety of supervisory cultures and governance arrangements which could make coordination even more difficult. While the obstacles created by such heterogeneity are not insurmountable, they could certainly throw sand in the wheels of smooth and efficient supervisory coordination at the EU level. This is a reality that European policymakers did not face when setting up the ECB and the ESCB. Central banks' cultures are less diverse than supervisory cultures. Moreover, central banks transferred their monetary policy prerogatives to the ECB, while supervisors retain under the adopted framework their powers over the domestic financial system. So the coordination and communication issues are of a different order now. Some of the implications of the co-existence of a wide variety of architectures will come out more clearly when the architectures are considered in conjunction with their governance structures in the next section.

Finally, one also needs to bear in mind that a number of studies (e.g., Masciandaro, 2006, Westrup, 2007, and Masciandaro and Quintyn, 2008) show that revealed preferences with respect to national supervisory architectures often stemmed from political considerations (such as politicians fearing that independent central banks in charge of supervision would prevent politicians from keeping or having any influence on financial sector developments). In other cases, central banks were able to throw their weight in the discussion and managed to secure (or expand) their supervisory powers. Against the background of this reform record, it now remains to be seen whether individual countries will be inclined to revisit their supervisory architectures in light of the emerging European framework. Given that the European framework can also be subject for revision, one could also imagine some emerging competition among various architectures going forward.

\footnotetext{
${ }^{21}$ Several representatives of national authorities have also in private conversations with the authors of this paper alluded at the problems that these difference created at the time they were establishing a unified supervisor.
} 


\section{CONVERGENCE IN SUPERVISORY GOVERNANCE}

In sharp contrast with the debate on independence of the central bank's monetary policy function, the terrain with respect to financial regulatory and supervisory governance remained relatively uncharted until recently. Somehow, it was assumed in the literature that, for those central banks that also performed supervisory functions, the independence in monetary policy spilled over into the supervisory functions. Almost no attention went to the governance of those supervisory agencies that were not housed in the central bank.

As argued in Das and Quintyn (2002) and Quintyn (2007), attention for governance arrangements for supervisors is needed because the job content of supervisors has been changing profoundly in response to the worldwide liberalization of financial sectors. Prudential supervisors are nowadays "governance supervisors" who monitor, on behalf of depositors and tax payers, the quality of the supervised institutions' governance arrangements (Dewatripont and Tirole, (1994). Quintyn (2007) shows that solid governance arrangements for financial supervisors - built around arrangements for independence, accountability, transparency and integrity - are a precondition for effective supervision. More specifically, Quintyn and Taylor (2003 and 2007) and Hüpkes et al. (2005) made the case for independence and accountability of supervisory agencies and spelled out the operational implications.

These papers also argue that accountability arrangements of financial supervisors in a democratic environment must necessarily be more complex than for monetary policy authorities owing to: (i) their multiple, and harder to measure objectives; (ii) the existence of a multiple principals environment; and (iii) the extensive legal powers typically conferred on them in combination with their legal immunity. It has been further argued that from a social welfare standpoint independence and accountability should not be regarded as mutually exclusive but are complementary to the extent that well-designed accountability arrangements can help to buttress agency independence.

Assuming that the theoretical case for independence and accountability is accepted, this section draws on the earlier work of Quintyn, Ramirez and Taylor (2007) (hereafter called QRT) which established a framework for analyzing and rating independence and accountability arrangements for bank supervisors based on their legal frameworks (de iure measurements). ${ }^{22}$ QRT define 19 criteria to measure supervisory independence and 22 for the quality of accountability arrangements (Table 2). We refer to QRT (2007) for a detailed discussion of the methodology and the sources of information (mainly national regulations). A rating of " 2 " is given if the law satisfies the criteria, a "1" is given for partial compliance, and a "0" for non compliance. In some cases a " 1 " is given for what are considered practices that undermine

\footnotetext{
${ }^{22}$ We focus on bank supervision, given its central and crucial role in preserving the overall financial stability in the EU, and by extension in most countries around the globe. We are aware that, where the institutional setting is the sectoral model, a complete analysis would require the examination of the other agencies as well.
} 
independence or accountability. ${ }^{23}$ The individual ratings are summed and normalized between 0 and $1 .{ }^{24}$ Our sample contains 14 countries where bank supervision is part of the central bank's responsibilities ${ }^{25}$ and 13 countries where an agency, separate from the central bank is in charge of banking supervision. ${ }^{26}$

\section{A. Measuring Independence}

The criteria for independence are regrouped hereafter into three different dimensions: institutional; regulatory and supervisory, and budgetary independence. Regulatory and supervisory independence form the core, while institutional and budgetary independence are essential to support the execution of the core functions. The Basel Committee on Banking Supervision recognized the importance of supervisory independence by making it part of its first "Core Principle for Effective Bank Supervision" (Basel Committee, 1997 and 2006):

Basel Core Principle 1: "An effective system of banking supervision will have clear responsibilities and objectives for each agency involved in the supervision of banks. Each such agency should possess operational independence and adequate resources..."

\section{Institutional Independence}

Institutional independence refers to the status of the agency as an institution separate from the executive and legislative branches of government. The following are two critical elements of institutional independence. First, independence is best served if there are clear rules on the terms of appointment and dismissal of the agency's senior personnel. Under such rules regulators would enjoy security of tenure, enabling them to speak and take action without fear of dismissal by the government of the day. Ideally, both the executive and legislative branches of government should be involved in the appointment process. Second, regarding the agency's governance structure, collegial decision-making structures are considered better than systems where the chairperson solely takes the decisions.

QRT consider 9 criteria to assess institutional independence. Figure 5 shows that ten countries have a high degree of compliance (throughout, we use as rule of thumb a level of the index equal or greater than 75 percent to indicate high compliance), while two countries have granted less institutional independence to their unified supervisory agency.

\footnotetext{
${ }^{23}$ For example in some European countries the Minister of Finance has retained (some) oversight power on supervisionAustria, Cyprus, Denmark, Estonia, Germany, Greece, Hungary-or a government representative is on the agency's policy board-Estonia, Finland, France, Germany, Latvia, Poland, Spain and Sweden.

${ }^{24}$ Given an indicator, for each country the normalized value of the ranking is the ratio between the absolute value of the indicator and the maximum value reached in the sample of the 27 EU countries.

${ }^{25}$ Bulgaria, Cyprus, Czech Rep., France, Greece, Ireland, Italy, Lithuania, Netherlands, Portugal, Romania, Slovak Rep., Slovenia and Spain.

${ }^{26}$ Austria, Belgium, Denmark, Estonia, Finland, Germany, Hungary, Latvia, Luxembourg, Malta, Poland, Sweden and UK.
} 
From the point of view of coordination/centralization in the EU, three criteria for institutional independence, seem super-critical and therefore warrant a more detailed analysis: legal immunity of supervisors; presence of government officials on policy boards, and dismissal procedures for presidents and senior management.

Legal immunity. Despite the high degree of compliance on independence, we notice that, on this dimension, supervisors in a large number of EU 27 countries do not possess legal immunity when exercising their job in good faith. Legal immunity is unanimously considered a conditio sine qua non for effective supervision. Lack of immunity may prevent supervisors from taking decisive actions, thereby creating forbearance. In a system that relies heavily on home-country supervision, forbearance in one country could easily and quickly spread across the EU, thereby reducing the incentives to cooperate. Legal immunity (or the lack thereof) must also be seen in conjunction with judicial accountability (see below).

Government officials on policy boards. The EU countries are relatively heterogeneous with respect to the presence of government officials on supervisory policy boards, often as chair persons. More specifically, several recent members from Central and Eastern Europe have kept or adopted this practice. Having government officials in decision-making positions undermines supervisory independence from the political process. Our findings also show that in those countries where government officials are on policy boards, accountability towards legislative and executive branches is relatively underdeveloped, which in itself opens the door to other forms of unequal treatment of supervisors. Having politicians in decision-making positions could potentially lead to issues such as slowing down the adoption of EU Directives, favouring national interests through regulatory processes, promoting national financial institutions or champions, shifting the regulatory burden to other countries, or domestically applying forbearance for short-term political gain. All these outcomes would have an impact on coordination among national supervisors and, ultimately on the effectiveness of the European supervisory framework. While such practices may also emerge under independent supervisors, they are more likely to surface when politicians have a direct say in the supervisory process.

Dismissal procedures. Several EU countries do not stipulate specific dismissal procedures for agency presidents and senior management. Again, this could potentially undermine political independence of the regulatory and supervisory process and foster self capture.

In an analysis of the quality of regulatory and supervisory arrangements in Europe, based on the IMF-WB FSAPs, Čihàk and Tieman (2007) come to similar conclusions, based on scores with respect to the Basel Core Principles which are less detailed on regulatory governance than our criteria. They find that "The most frequent weaknesses relate to the potential for political interference in day-to-day supervision, the lack of budgetary independence and the need to strengthen the legal protection of supervisors" (italics are ours). 


\section{Regulatory and Supervisory Independence}

Regulatory independence refers to the ability of the agency to have an appropriate degree of autonomy in setting those fundamental prudential rules and regulations for the sectors under its supervision, within the confines of the country's broader legal framework. ${ }^{27}$ A high degree of autonomy in setting prudential regulations is expected to help in ensuring that the financial sector complies with international best standards and practices. Lack of autonomy introduces risks that revisions are unnecessarily spun out over time, or that regulatory capture by government or industry may result in regulatory forbearance.

Supervisory independence concerns the independence with which the agency is able to exercise its judgment and powers in such matters as licensing, on-site inspections and off-site monitoring, sanctioning, and enforcement of sanctions (including revoking licenses) which are the supervisors' main tools to ensure the stability of the system. The need for adequate authority is also recognized by the Basel Committee on Banking Supervision:

Basle Core Principle 23: "Banking supervisors must have at their disposal adequate supervisory measures to bring about timely corrective action when banks fail to meet prudential requirements (such as minimum capital adequacy ratios), when there are regulatory violations, or where depositors are threatened in any other way. In extreme circumstances, this would include the ability to revoke the banking license or recommend its revocation."

Supervisory independence is arguably the most difficult aspect of independence to guarantee. To preserve its effectiveness, the supervisory function typically involves private ordering between the supervisor and the supervised institution. But the privacy of the supervisory process makes it vulnerable to interference, both from politicians and supervised entities. Such interference can take many forms and can indeed be very subtle, making it difficult to shield the supervisors from all forms of interference. Some argue therefore that critical supervisory actions (such as "intervening" a financial institution) should be rules-driven to avoid that too much discretion leads to forbearance. ${ }^{28}$

QRT identify five criteria to assess regulatory and supervisory independence. Figure 6 shows that EU countries are highly compliant in this regard. Two criteria deserve particular attention: regulatory independence and licensing powers.

Regulatory independence. Supervisors in a minority of EU countries do not have the autonomy to define the prudential regulatory framework. In a number of countries constitutional rules do

27 Prudential regulations cover general rules on the stability of the business and its activities (e.g., fit and proper requirements for senior management), as well as specific rules that follow from the special nature of financial intermediation (risk-based capital ratios, limits on off-balance sheet activities, definition of limits on exposure to a single borrower, limits on connected lending, loan classification rules, and loan provisioning rules).

${ }^{28}$ See Nieto et al. (2008) for arguments why EU countries should adopt rules-based intervention policies. 
not allow the rulemaking prerogative to be given to agencies. These limitations could hinder cross-border coordination of regulation and an homogeneous transposition of the EU Directives.

Licensing and withdrawing licenses. This remains a sensitive area in a number of EU members. Several countries in the EU prefer to keep a role for the government in the area of licensing - and even more withdrawing licenses (e.g., Italy and Spain). Unlike for some other criteria, there is no dividing line here between the "old" and "newer" members. While some governments have retained this role only as a formality, several others wish to keep an active role in the process of closing a financial institution. An active government role in withdrawing licenses delays, at the minimum, supervisory action and increases supervisors' incentives to forbear, which could be particularly conspicuous in cross-border supervision. In the worst case, it opens the door to political considerations with respect to the composition and operation of a country's financial system.

\section{Budgetary Independence}

Budgetary independence refers to the ability of the agency to determine the size of its own budget and the specific allocations of resources and priorities that are set within the budget. Regulatory agencies that enjoy a high degree of budgetary independence are better equipped to withstand political interference (which might be exerted through budgetary pressures), to respond more quickly to newly emerging needs in the area of supervision and to ensure that salaries are sufficiently attractive to hire competent staff.

Funding via a levy on the regulated reduces the risks typically associated with funding from the government budget. To avoid industry capture and ensure that the fees are reasonable, in some countries, their level is determined jointly by the regulatory agency and the government. Feebased funding is also vulnerable to the risk that the regulator's resources will be most limited when the industry is under strain. If, for whatever reason, there is a consensus that funding needs to come from the government budget, the budget of supervision should be proposed and justified by the agency, based on objective criteria related to developments in the markets. Masciandaro, Nieto and Prast (2007) analyze the financing of banking supervision in 90 countries (including the EU countries). They show that supervisors housed in the central bank are in most cases funded through the latter's budget, while supervision funded via a levy on the regulated banks is more likely in the case of a separate financial authority, with some countries applying mixed funding. In general, there seems to be a trend toward more private funding. At the EU level, some degree of cross-country convergence in matters of budgetary independence is desirable. Large discrepancies in fee structures may disturb level playing field conditions among supervisors in the EU with respect to their input of supervisory efforts.

QRT use five criteria to assess the degree of budgetary independence. Figure 7 shows that 16 EU countries are highly compliant with the criteria, with only one country-Malta-significantly diverging. Čihàk and Tieman (2007) listed the lack of budgetary independence among the main weaknesses in the European supervisory frameworks. 


\section{B. Measuring Accountability}

The criteria for accountability, defined in QRT, are regrouped into three dimensions: political accountability, judiciary accountability and transparency — mainly accountability arrangements versus other stakeholders (Table 3).

\section{Political Accountability (towards Legislative and Executive Branches)}

In most systems of government the legislative branch plays a vital role overseeing the activities of the executive branch in virtue of its representative character. The objective of its oversight is to ensure that public policy is administered in accordance with legislative intent. The key is that the supervisors should be accountable "ex post" to the political authorities for the appropriateness of their actions.

Since the principles of regulatory regimes are normally promulgated by parliament, the latter should be a primary actor charged with holding the financial regulator accountable for meeting the stated objectives in its mandate. ${ }^{29}$ This can be achieved through regular institutionalized contacts between the regulatory agency and parliament (or a parliamentary committee). Parliament's influence on the regulatory activities ought to be exerted primarily through its lawmaking powers, i.e., by making changes to the legal framework when needed.

An independent agency also needs to have a direct line of accountability to the executive branch because the latter bears the ultimate responsibility for the general direction and development of financial policies, and the minister of finance needs to be aware of developments in the financial system, given the government's active role in financial crisis management. Formal channels of communication should include the annual report, as well as regular reporting (monthly, quarterly). Masciandaro, Nieto and Prast (2007) find anecdotal evidence that public financing of supervisory agencies is more associated with accountability towards Parliament, while private financing seems to go hand in hand with an emphasis on accountability towards government.

The executive branch also has an important role to play in the appointment of the senior officials of the regulatory agency. In many countries they are appointed by the government or by the head of state upon recommendation by the government or finance minister. Best practice would imply the involvement of two branches of government to ensure checks and balances: the legislative branch appointing senior officials, upon recommendation of the government. While the right to appoint the chief executive and/or members of the agency's board for a fixed term enhances independence, the right for removal on clearly specified grounds, is an indispensable accountability mechanism. ${ }^{30}$

\footnotetext{
${ }^{29}$ In Westminster-type of systems, accountability to parliament typically goes through the minister who bears the final responsibility of the activities of the financial regulator. This helps explain the low rate of compliance for the UK.

${ }^{30}$ Dismissal procedures are of relative value if dismissal is limited to cases of malfeasance. In no instance is serious misconduct interpreted as including the failure to discharge functions properly in accordance with the statutory objectives of the financial regulator and thus in terms of bad performance (Amtenbrink, 1999).
} 
QRT identify eight criteria to assess the degree of the political accountability. Figure 8 shows that four countries have the highest ratios, while two countries-Denmark and UK-are at the bottom.

\section{Judiciary Accountability (towards Judiciary Branch)}

Given the extensive legal powers typically conferred on regulatory agencies in combination with their legal immunity, judicial review is a cornerstone of their accountability relations in respect of supervisory measures. Any independent agency should be accountable "ex post" to the judicial system for the legality of its actions. The former should have some right of legal redress in court. Judicial review provides a procedure whereby the courts oversee the exercise of public power. Traditionally, the purpose of judicial review of administrative action is to ensure that the decision-maker acts within its powers.

Individuals or institutions subject to the agency's decisions should also have the right to apply to a judicial authority for review of those decisions. The agency must indeed observe a number of due process requirements when it takes decisions such as issuing or withdrawing licenses and imposing sanctions. Once a formal decision has been taken, the party to whom the decision is addressed must be informed of his or her legal remedies. The purpose of these requirements is to ensure the procedure to be as transparent as possible and that it results in a fair and just decision.

There should also be a form of substantive accountability (judicial review of the substance of supervisory measures). The difficulty here is that the discretion conferred on a supervisor is typically broad and courts in practice prefer to exercise restraint and defer to the expert knowledge of the supervisor given that they do not normally possess the expertise in financial matters and are therefore reluctant to substitute their judgment on supervisors. Substantive accountability is therefore often limited to review of legality with a view to ensuring that discretion is not exercised in bad faith or for improper purposes. ${ }^{31}$ Substantial review needs to be limited and time-bound in order to avoid that the process will stand in the way of regulatory and supervisory efficiency and effectiveness and ultimately undermine agency independence.

In the event that a regulatory agency is found to have breached its legal duties, the plaintiff must have some remedy available. However, the need to ensure agency independence means that there should be a variety of limitations on liability for faulty supervisory action. Any official of an agency who took action in good faith should not be held personally liable for damages caused in the exercise of his functions. Because rules on immunity and limited liability of the supervisor are correlates of independence, their existence needs to be compensated by appropriate accountability arrangements including judicial review and a procedure that offers administrative compensation in cases were loss was suffered due to unlawful action by the agency.

\footnotetext{
${ }^{31}$ Hüpkes (2000).
} 
QRT identify the criteria to assess the accountability to the judiciary branch. Figure 9 shows that compliance with this aspect of accountability is somewhat problematic in the EU: only seven countries-Finland, Ireland, Netherlands, Malta, Portugal, Sweden, and UK-reach high ratios, while as many as twelve do not. Only few EU countries have elaborate mechanisms of judicial accountability. Several countries do not provide for rights of appeal by institutions affected by supervisory decisions. Likewise, only few countries' legislation provides for penalties for supervisory mistakes. Lack of proper mechanisms for judicial accountability could have several repercussions. On the one hand, the need for judicial accountability mechanisms must be seen as a counterweight against the right to legal immunity (see above) and the broad sanction and enforcement powers typically conferred to supervisors. This is a clear example of a case where independence can become ineffective, if not put in a context of accountability arrangements. Extreme differences in judicial accountability could potentially lead to regulatory arbitrage - financial institutions looking for countries where arrangements are most favourable — or forms of regulatory capture —weaker judicial practices that lead financial institutions to influence the regulatory process in specific countries.

\section{Transparency}

The critical elements of transparency relate to the decision making of supervisory action to all stakeholders. Inherent in financial supervision is the fact that many decisions involve commercially sensitive material that would be delicate to disclose. But the presumption should be in favor of openness in the decision-making process, making it possible for both the public and the industry to scrutinize regulatory decisions minimizing the risk of political interference. Moreover, in the prevailing institutional framework in the EU based on the principle of "home control," and the existence of "supervisory colleges" 32 the possibility of asymmetric information tends to reduce or undermine mutual trust and incentives to cooperate among supervisory agencies. In order to address these potential problems, supervisors need to be ensured that their counterparts in other jurisdictions comply with all accountability and transparency arrangements and that there is maximum openness towards peers.

An important instrument of agency accountability is the presentation of financial accounts, demonstrating the regularity of expenditures. Masciandaro, Nieto and Prast (2007) find that, in the case of prudential supervisors housed in central banks and financed exclusively through seigniorage, the budgeting process and financial statements are in general those of the central bank (e.g., The Netherlands, Spain and Portugal). They also share financial statements in the case of prudential supervisors financed by supervised institutions that operate within central banks and, as a consequence, do not have separate assets and liabilities (e.g., Ireland).

To avoid that this aspect of accountability would undermine agency independence by the back door, financial accountability should be limited to ex post accountability, focusing on a review of the annual accounts and balance sheets by independent auditors to determine whether there

\footnotetext{
${ }^{32}$ For an earlier account on the problems with home country control, see Mayes and Vesala (1998).
} 
has been proper financial management, whether the authority is managing its resources in an efficient way, and whether financial reports represent a true and fair view.

The EU countries show a high degree of compliance with the transparency criteria. Some areas of accountability and transparency vis-à-vis stakeholders, such as consultation processes with supervised entities, consultation with the public at large, are not very developed in most EU countries (although the process is well established at the EU level in the context of the Lamfalussy architecture). Insufficient consultation and transparency may result in an uneven transposition of EU directives at the national level as well as in limited convergence of supervisory practices. Figure 10 shows that 10 countries are highly compliant with the 10 criteria defined in QRT. No country seems to be way out of line.

\section{Is There Governance Convergence Within the EU?}

Governance, in the words of Williamson (2000) “... is an effort to craft order, thereby to mitigate conflict and realize neutral gains. So conceived a governance structure obviously reshapes incentives" (italics are ours). By extension, and in the context of the ESFS, governance arrangements serve to (i) craft order, internally in the agency, and between the agency and its stakeholders which include in the new European setting, the other national agencies and the European-level agencies; (ii) mitigate conflict between the agencies and their stakeholders; and (iii) assist in realizing neutral gains for all stakeholders, i.e. to assure that the division of labor and the delegation of powers to the different layers in the ESFS is a socially optimal solution. Hence, the ESFS, and the individual countries have an interest in harmonizing their governance arrangements to align their incentive structures in order to achieve the EU-wide supervisory objectives.

So, do we see convergence in governance arrangements among EU countries? The general answer is a cautious "yes" but with some important proviso's nevertheless. Indeed, close inspection of the results reveals some issues that deserve attention in the run-up to the implementation of the ESFS. Before we enter the details, it is worthwhile emphasizing the positive aspects of our analysis. First of all, the analysis in Čihàk and Tieman (2007) and (2008), QRT (2007), and Masciandaro, Quintyn and Taylor (2008) show that regarding regulatory governance, European supervisors have, on average, the highest degrees of compliance in a worldwide sample. QRT (2007) also show that governance arrangements have on average improved more than in the rest of the world. Finally, these studies, and Čihàk and Fonteyne (2009) also show that governance arrangements in the "old" Europe have on average higher degrees of compliance than those in "new" Europe, a finding that we also pointed out in this paper for a number of issues. ${ }^{33}$

\footnotetext{
${ }^{33}$ As indicated before, Čihàk and Tieman (2007) and (2008) and Čihàk and Fonteyne (2009) rely on Basel Core Principles assessments to evaluate regulatory governance. The criteria used in these assessments are less detailed than the ones used on this paper.
} 
Despite these positive trends, weaknesses and lack of convergence certainly remain. More specifically, four broad themes emerge from our analysis. First, regarding total independence and accountability, from Figures 11 and 12 we observe a fair degree of convergence on independence, with 16 countries above the 75 percent mark. There is clearly a lesser degree of compliance and convergence on accountability. Only one country is above the 75 percent of compliance and the scores are for all countries much lower. These findings are in line with earlier findings in QRT (2007) and Masciandaro, Quintyn and Taylor (2008) for broader samples of countries.

From this findings follows a second one. Levels of independence and accountability seem to be only weakly correlated. To illustrate this, Figure 13 plots the two dimensions against each other, as well as the median values for each dimension. Our separation of the countries into four quadrants illustrates the heterogeneity of the sample. Countries in the above right quadrant show the highest levels of independence and accountability; the countries in the above left quadrant have only high levels of accountability; finally, the countries in the lower right quadrant show only high levels of independence. This finding is also in line with Masciandaro, Quintyn and Taylor (2008) who empirically find that degrees of supervisory independence and accountability are determined by different sets of variables in the countries: levels of independence are more related to some sort of demonstration effect (others have it, so we should have it too) and the level of democracy, while levels of accountability are more driven by the quality of public sector governance and the levels of supervisory unification. More integrated supervisors, who are also the "newer" institutions tend to pay more attention to well-structured accountability arrangements. More generally, this means that countries have not really grasped the idea that accountability and independence are mutually reinforcing institutional arrangements.

Thirdly, elaborating on this last observation, differences in independence and accountability scores are observed according to the location of financial supervision (Figure 14). Supervisors located inside the central bank have typically the highest degree of independence, but have also the least elaborate accountability arrangements. Supervisors located outside the central bank enjoy lower degrees of independence, combined with more developed accountability arrangements. Figures 14A and 14B show respectively the level of three dimensions of independence and accountability, disentangling supervisors located inside and outside the central bank. Supervisors located inside central banks enjoy higher degrees of institutional and budgetary independence - they "piggy back" on the arrangements ensuring monetary policy independence. On the other hand, supervisors outside central bank score higher on regulatory and supervisory independence, most likely because this is their sole mandate, whereas for central banks, supervision is not their prime task. Regarding accountability, supervisors in central banks score higher on political accountability but fall behind on judicial accountability and transparency. These two are "newer" forms of accountability and the fact that supervision is not their main mission, combined with inertia in institutional reform, could explain why these newer forms have not (yet) penetrated central banks to the same extent as new supervisory agencies. For the sake of illustration, charts 15 to 41 give a country by country overview using the six indicators of independence and accountability.

Finally, our analysis shows that the devil is in the details. It is indeed necessary to go beyond the general levels of independence and accountability. For both we singled out a number of individual criteria that are more crucial than some others for smooth European supervisory 
coordination, and where we identified significant differences among countries. The most critical ones are the lack of legal protection for supervisors, the presence of politicians on decisionmaking boards, the shared responsibilities regarding the right to license and withdraw licences on the independence side, and weak judicial accountability mechanisms. We pointed out how weaknesses (and great differences) in these areas could potentially undermine cooperation and coordination in supervisory matters because they could undermine national (and European) supervisors trust in each other's information gathering capacities, intervention powers and supervisory intentions and actions - the cornerstones of the European supervisory edifice. Upward harmonization of governance arrangements is necessary to reshape and align incentive structures of the national supervisors in the European context.

It should be noted that this analysis only (or mainly) covers the main supervisor in each country. A broader analysis that includes governance arrangements for other supervisors (securities markets, insurance) is outside the scope of this paper. However, without going into the details, as indicated before, one can see that the issues we have highlighted here will be compounded once all sectoral supervisors are brought into the picture. Cihàk and Tieman (2008) and Seelig and Novoa (2009) show that, in particular, insurance supervisors typically have weaker governance arrangements than bank supervisors.

\section{Conclusions and Policy Considerations}

In recent months, the EU authorities have taken decisive steps to strengthen the European financial supervisory framework in response to the financial crisis which damaged the EU financial system and (the reputation of) its supervisory framework fairly badly. The new framework will consist of a macro- and a micro-prudential pillar. The micro-prudential pillarthe focus of this paper-will consist of three levels: a Steering Committee, three supranational supervisory authorities (ESA), and at the lower level, the network of national supervisory authorities.

According to the Commission document, the ESA's will have far-reaching powers vis-à-vis the national supervisory authorities. However, the latter will also retain their full powers with respect to the oversight of the domestic financial system. Intertwined in this network of European and national supervisors are also the existing home-host supervisor relations, as well as the supervisory colleges, in charge of oversight of cross-border institutions. So, the emerging structure is a complex multiple principals - multiple agents web, which, in order to produce efficient and effective supervision need to be governed by incentive-compatible arrangements.

The network of national supervisors is characterized by two crucial features - their architecture and their governance arrangements - that have a great impact on the incentives. ${ }^{34}$ These are two separate features, but they also interact with each other in a number of important ways. A systematic comparison of the two features across the EU members and an analysis of their impact on future cooperation has thus far not been undertaken.

\footnotetext{
${ }^{34}$ The quality of the regulatory framework is a third crucial feature, but is outside the scope of this paper.
} 
This paper intended to fill some of the voids in our understanding of the potential implications of differing supervisory architectures and governance arrangements for the effectiveness of future EU financial regulation and supervision. We start from an analysis of current landscape in supervisory architectures and governance practices of the main supervisor (mainly banking supervisor) in each country. Subsequently we identify those areas where lack of cross-country convergence could lead to failures in providing national supervisors the right incentives to cooperate across borders, and hence, could undermine the effectiveness of EU supervision.

On supervisory architecture, the paper finds that the EU landscape is polarized with, at the one extreme a number of unified supervisors, and at the other a large number of fragmented systems (sector-specific supervisors), with a few countries not belonging to these extremes. Typically in the fragmented systems, the central banks are in charge of banking supervision (hence, the central bank-fragmentation effect). Building on the Lamfalussy-framework, the politicallyendorsed plan for the EU also establishes a sector-specific system at the supranational level. While there is no such thing as best practice in terms of supervisory architecture, it is clear that inter-agency coordination issues could arise from this heterogeneous supervisory landscape, particularly when we take into account the diverse supervisory cultures and governance arrangements that are associated with these diverse architectures. It also remains to be seen what the reactions to this heterogeneity will be, both at the supranational and the national levels, once frictions and coordination failures surface. Will there be another (spontaneous) round of reforms at the national level (a process that should be interesting to observe, given that several national architectures have emerged from country-specific political-economic considerations)? Or will there eventually be some pressure for harmonization coming from the European level?

On governance arrangements, the paper finds that the degree of independence is relatively high among EU members, while the degree of compliance with accountability is much lower, and compliance is also less homogeneous. From this, we deduct that independence and accountability are not perceived as two sides of the same coin, which certainly hampers the solidity of the agencies' governance. Our findings also showed that supervisory architecture matters: supervisors housed in central banks are more independent that others, while their accountability arrangements are less developed (or to a lesser extent geared towards the supervisory tasks).

Unlike for the architectures, a set of best governance practices is emerging in the literature and our analysis shows that, given the complexities involved in establishing coordination and cooperation in the emerging European supervisory framework, intra-European harmonization towards best practices in independence and accountability is highly desirable, including for the new ESAs. Such upward harmonization would align the incentive structures of all partners by (i) increasing incentives to reduce forbearance of national supervisors and to cooperate among them; (ii) limiting self capture and industry capture by strengthening the principle-agent relation between the tax payer and the supervisor; (iii) promoting independence from the political branch of power; and (iv) fostering a level playing field among supervisors and supervised institutions.

While not all aspects of independence and accountability need to be fully harmonized, we pointed out some crucial issues that need to be addressed, such as (i) the need for legal 
protection for supervisors handling in good faith and (ii) for budgetary independence; (iii) the issue of the presence of politicians on decision-making bodies; (iv) the need for supervisory autonomy in matters of licensing and withdrawing licenses; and lastly, (v) the need for mechanisms for judicial accountability. Upward harmonization of governance arrangements will be crucial in order to have incentive-compatible structures conducive for interagency information sharing, building mutual trust and cooperation to achieve the pan-European goal of financial stability.

In order to expedite, or facilitate, this process, and secure the right outcomes, this paper finishes with two possible policy recommendations:

- $\quad$ First, one may wonder if some guidance from the European level with respect to the harmonization of governance arrangements could be useful. The creation of the ECB and the ESCB was preceded by a number of mandatory changes in the governance structure of the prospective members' central banks under the Maastricht Treaty. Some similar process - through recommendations or mandatorily - could be envisaged now for the ESFS.

- $\quad$ Second, one could also think about the introduction of a European mandate for national supervisors (Hardy, 2009) in order to better align incentives among the networkparticipants. While attractive from the point of view of aligning incentives, the promulgation of a European mandate would raise another set of governance issues. Adopting a European Mandate would imply that lines of accountability from national supervisors to (some) European institutions (this could be the ESA) be established. Keeping the lines of accountability to the national branches of government only would not guarantee proper compliance with the European mandate because national legislative and executive branches may be tempted to still look at their national interests in the first place, or fail to grasp the European dimension of financial stability related to the issues posed before them. 


\section{References}

Abrams, R.K., and M.W. Taylor, 2002, "Assessing the case for unified sector supervision," FMG Special Papers No. 134, Financial Markets Group (London: London School of Economics).

Arnone, M., A. Gambini, 2007, “Architecture of Supervisory Authorities and Banking Supervision," in Designing Financial Supervision Institutions: Independence, Accountability and Governance, ed. by Donato Masciandaro and Marc Quintyn (Cheltenham: United Kingdom; Northampton, Massachusetts: Edward Elgar).

Bini Smaghi, 2009, "Going forward: Regulation and Supervision after the Financial Turmoil," paper presented at Finlawmetrics 2009 "After the Big Bang: Reshaping Central Banking, Regulation and Supervision, Bocconi University, Milan, June 18 - 19.

Capie, F., 2007, "Some Historical Perspective on Financial Regulation," in The Structure of Financial Regulation, ed. by D.G. Mayes and G.E. Wood (London and New York: Routledge), pp. 43-65.

CEPS, 2008, "Concrete Steps towards More Integrated Financial Oversight," CEPS Task Force Report, December.

Čihàk, M., Podpiera, R., 2007a, "Experience with Integrated Supervisors: Governance and Quality of Supervision," in Designing Financial Supervision Institutions: Independence, Accountability and Governance, ed. by Donato Masciandaro and Marc Quintyn (Cheltenham: United Kingdom; Northampton, Massachusetts: Edward Elgar).

— 2007b, "Does More Integrated Supervision mean Better Supervision? Finlawmetrics 2007” Bocconi University (mimeo).

Čihàk, M., and A. Tieman, 2007, Assessing Current Prudential Arrangements, pp $171-198$ in Integrating Europe's Financial Markets, ”ed. by J. Decressin, H. Faruqee and W. Fonteyne (Washington, D.C.: International Monetary Fund).

— , 2008, "Quality of Financial Sector Regulation and Supervision around the World," IMF Working Paper WP/08/190 (Washington D. C., International Monetary Fund).

Čihàk, M., and W. Fonteyne, 2009, "Five Years After: European Union Membership and Macro-Financial Stability in the New Member States," IMF Working Paper WP/09/68 (Washington D. C., International Monetary Fund).

Commission of the European Communities, 2009, "Communication from the Commission. European financial supervision,” COM (2009) 252 final, 17 pp.

Council of the European Union, 2009, "Council conclusions on strengthening EU financial supervision," 2948 ${ }^{\text {th }}$ Economic and Financial Affairs, Luxembourg, June 9, 2009, 7 pp. 
Dalla Pellegrina, L., and Donato Masciandaro, 2008, "Politicians, Central Banks and the Shape of Financial Supervision Architectures," Journal of Financial Regulation and Compliance, Vol. 17., p. $290-317$.

Das, U., and M. Quintyn, 2002, "Financial Crisis Prevention and Crisis Management-The Role of Regulatory Governance," in Financial Sector Governance: The Roles of the Public and Private Sectors, ed. by R. Litan, M. Pomerleano, and V. Sundararajan, (Washington, D.C.: Brookings Institution Press).

de Larosière Group, 2009, "Report of the High Level Group on Supervision."

European Shadow Financial Regulatory Committee, 2005, "Reforming Banking Supervision in Europe," Statement No. 23.

Fleming, A., D.T. Llewellyn, and J. Carmichael, (Eds.), 2004, "Aligning Financial Supervision Structures with Country Needs," (Washington D.C.: World Bank Publications), pp 19-85.

Fonteyne, W., and J. W. van der Vossen, 2007, "Financial Integration and Stability," in Integrating Europe's Financial Markets," ed. by J. Decressin, H. Faruqee and W. Fonteyne (Washington, D.C.: International Monetary Fund).

García, G. H., and María J. Nieto, 2005, "Banking Crisis Management in the European Union: Multiple Regulators and Resolution Authorities," Journal of Banking Regulation, Vol. 6, No. 3, pp. 206-226.

Goodhart, C.A.E., 2007, "Financial Supervision from an Historical Perspective: Was the Development of Such Supervision Designed, or Largely Accidental?" in The Structure of Financial Regulation, ed. by D.G. Mayes and G.E. Wood, (London: Routledge, Chapman and Hall; New York: Routledge).

Goodhart, C.A.E., editor, 2000, "Which Lender of Last Resort For Europe?” (London: Central Banking Publications).

Hardy, D., 2009, “A European Mandate for Financial Sector Supervisors in the EU," IMF Working Paper WP/09/5 (Washington D. C., International Monetary Fund).

Holthausen, Cornelia, and Thomas Ronde, 2005, "Cooperation in International Banking Supervision,” Discussion Paper Series No. 4990, Center for Economic Policy Research.

Hüpkes, Eva H.G., 2000, “The Legal Aspects of Bank Insolvency.” (The Hague, The Netherlands: Kluwer Law International).

Hüpkes, E.H.G., M. Quintyn, and M. Taylor, 2005, "The Accountability of Financial Sector Supervisors: Theory and Practice," European Business Law Review Vol. 16, pp. $1575-1620$. 
Kremers, Jeroen, Dirk Schoenmaker and Peter Wierts (eds), 2003, "Financial Supervision in Europe" Edward Elgar, Cheltenham, UK and Northampton, MA, USA., 184pp.

Lastra, Rosa M., 2006, "Legal Foundations of International Monetary Stability” (London: Oxford University Press).

Masciandaro, D., 2004, "Unification in Financial Sector Supervision: The Trade-off Between Central Bank and Single Authority," Journal of Financial Regulation and Compliance, Vol. 12, No. 2, pp. 151-169.

Masciandaro, D., (Ed.), 2005, Handbook of Central Banking and Financial Supervision in Europe (Cheltenham: United Kingdom; Northampton, Massachusetts: Edward Elgar).

— Determinants," Open Economies Review, Vol. 17, No. 1, pp. 73-102.

— 2007, "Divide et Impera: Financial Supervision Unification and the Central Bank Fragmentation Effect," European Journal of Political Economy, pp. 285-315.

_ , 2008, "Politicians and Financial Supervision Outside the Central Bank: Why Do They Do it?" Journal of Financial Stability (forthcoming).

Masciandaro, D., M. Nieto, and H. Prast, 2007, "Who Pays for Banking Supervision? Principles and Trends," Journal of Financial Regulation and Compliance, Vol. 15, No. 3.

Masciandaro, D., M. Nieto, and M. Quintyn, 2009, "Financial Supervision in the EU: Is there convergence in the National Architectures?" Journal of Financial Regulation and Compliance, Vol. 17, No. 2, pp $86-92$.

Masciandaro, D. and M. Quintyn, 2008, "Helping Hand or Grabbing Hand? Politicians, Supervision Regime, Financial Structure and Market View," North American Journal of Economics and Finance.

Masciandaro, D., M. Quintyn, and M. Taylor, 2008, "Inside and Outside the Central Bank: Independence and Accountability in Financial Supervision. Trends and determinants," European Journal of Political Economy, Vol. 24.

Mayes, David, and Jukka Vesala, 1998, “On the problems of Home Country Control” Bank of Finland Discussion Paper 20/1998.

Mayes, David, Maria J. Nieto, and Larry Wall, 2008, “Multiple Safety Net Regulators and Agency Problems in the EU: Is Prompt Corrective Action partly the Solution?" Journal of Financial Stability, Vol.4, No. 3, pp 223-257.

Nieto, Maria J., and Juan Peñalosa, 2004, “The European Architecture of Regulation, Supervision and Financial Stability: A Central Bank Perspective," Journal of International Banking Regulation, 5(3), 2004, pp. 228-42. 
Nieto, Maria, and L. Wall, 2007, "Prompt Corrective Action: Is There a Case for an International Banking Standard?" Chapter 23 in International Financial Instability: Global Banking and National Regulation, ed. by D. Evanoff, G. Kaufman and J. La Brosse, World Scientific Studies in International Economics, Vol. 2.

Prati, Alessandro and Garry J. Schinasi (1999), Financial Stability in European Economic and Monetary Union, Princeton Studies in International Finance No. 86 (August).

Schoenmaker, D., 2003, "Financial Supervision: From National to European? Financial and Monetary Studies,” NIBE - SVV, Vol. 22, No. 1 (Amsterdam).

Quintyn, M, and M. Taylor, 2003, "Regulatory and Supervisory Independence and Financial Stability," CESifo, Economic Studies No. 49, pp. 259-94.

Quintyn, M., 2007, “Governance of Financial Supervisors and its Effects-A Stocktaking Exercise," SUERF Studies 2007/4, 64 pages.

Quintyn, M., and M. Taylor, 2007, “Robust Regulators and Their Political Masters,” in: Designing Financial Supervision Institutions: Independence, Accountability and Governance, ed. by Donato Masciandaro and Marc Quintyn (Cheltenham: United Kingdom; Northampton, Massachusetts: Edward Elgar).

Quintyn, M., S. Ramirez, and M.W. Taylor, 2007, "The Fear of Freedom. Politicians and the Independence and Accountability of Financial Supervisors," in Designing Financial Supervision Institutions: Independence, Accountability and Governance, ed. by Donato Masciandaro and Marc Quintyn (Cheltenham: United Kingdom; Northampton, Massachusetts: Edward Elgar).

Sacasa, Noel, 2008, "Preventing Future Crises," Finance and Development, Vol. 45 (December), Number 4, pp 11-14.

Seelig, Steven and Alicia Novoa, 2009, "Governance Practices at Financial Regulatory and Supervisory Agencies”, IMF Working Paper, forthcoming.

Williamson, Oliver, 2000, "The New Institutional Economics: taking stock, looking ahead." Journal of Economic Literature, Vol. 38, No. 3, pp 595-613.

Wirtschaftswoche, 2009, "EZB fordert Verantwortung für Europäische Bankenaufsicht," January 3 . 
Figure 1 Financial Supervisory Regimes: number of reforms per year (1998-2008)

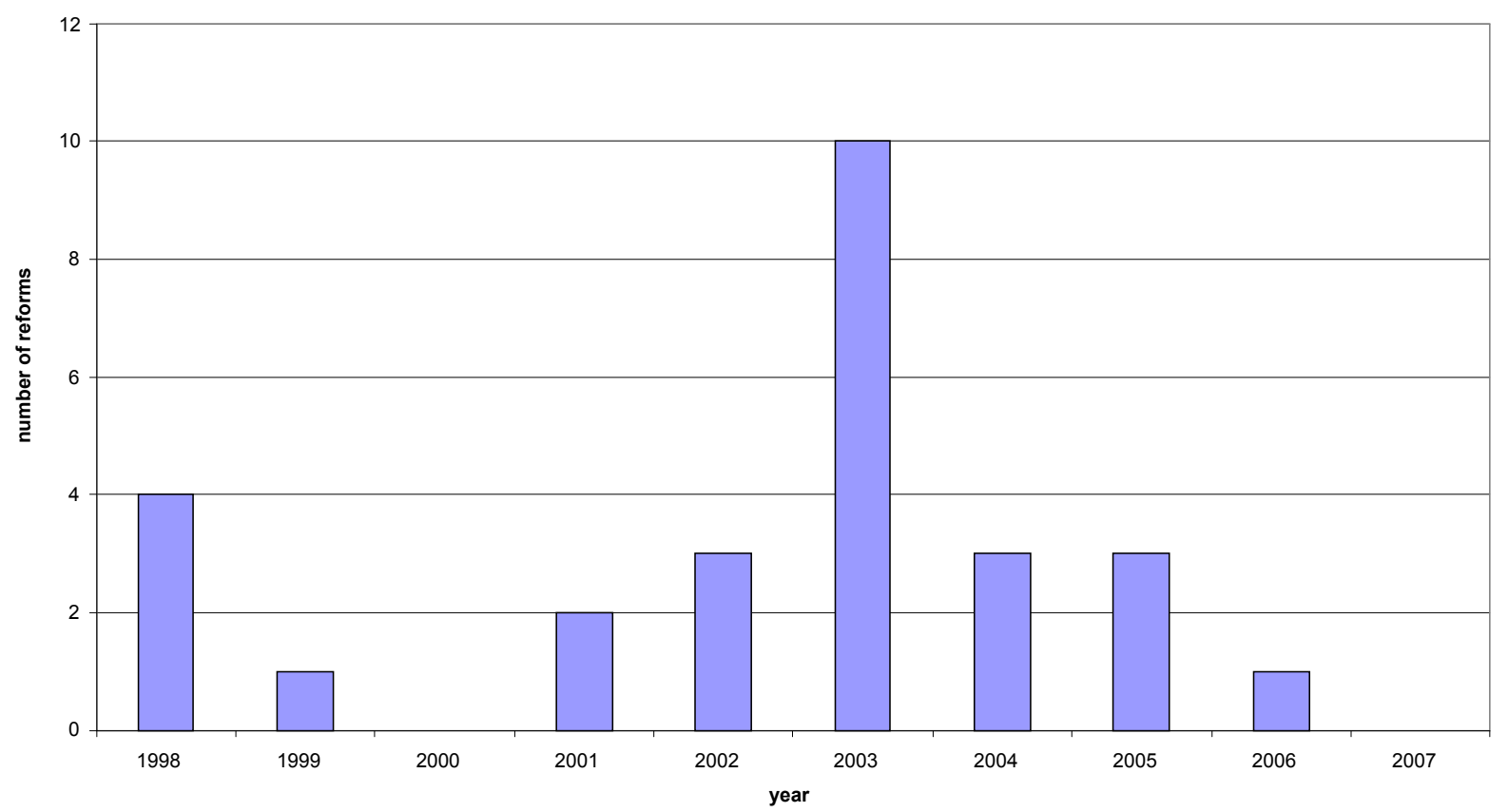


Figure $1 \mathrm{~A}$.

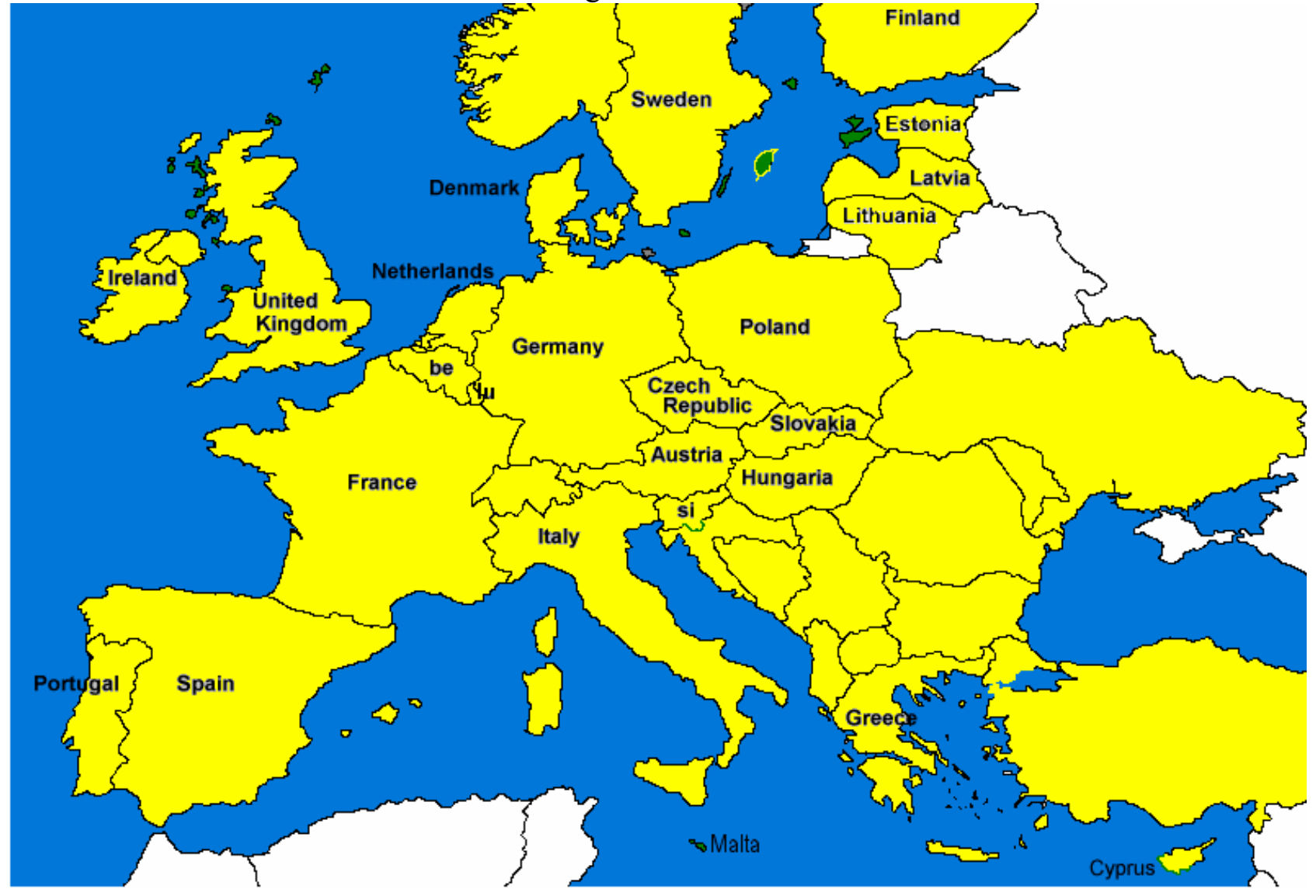


Figure 1B.

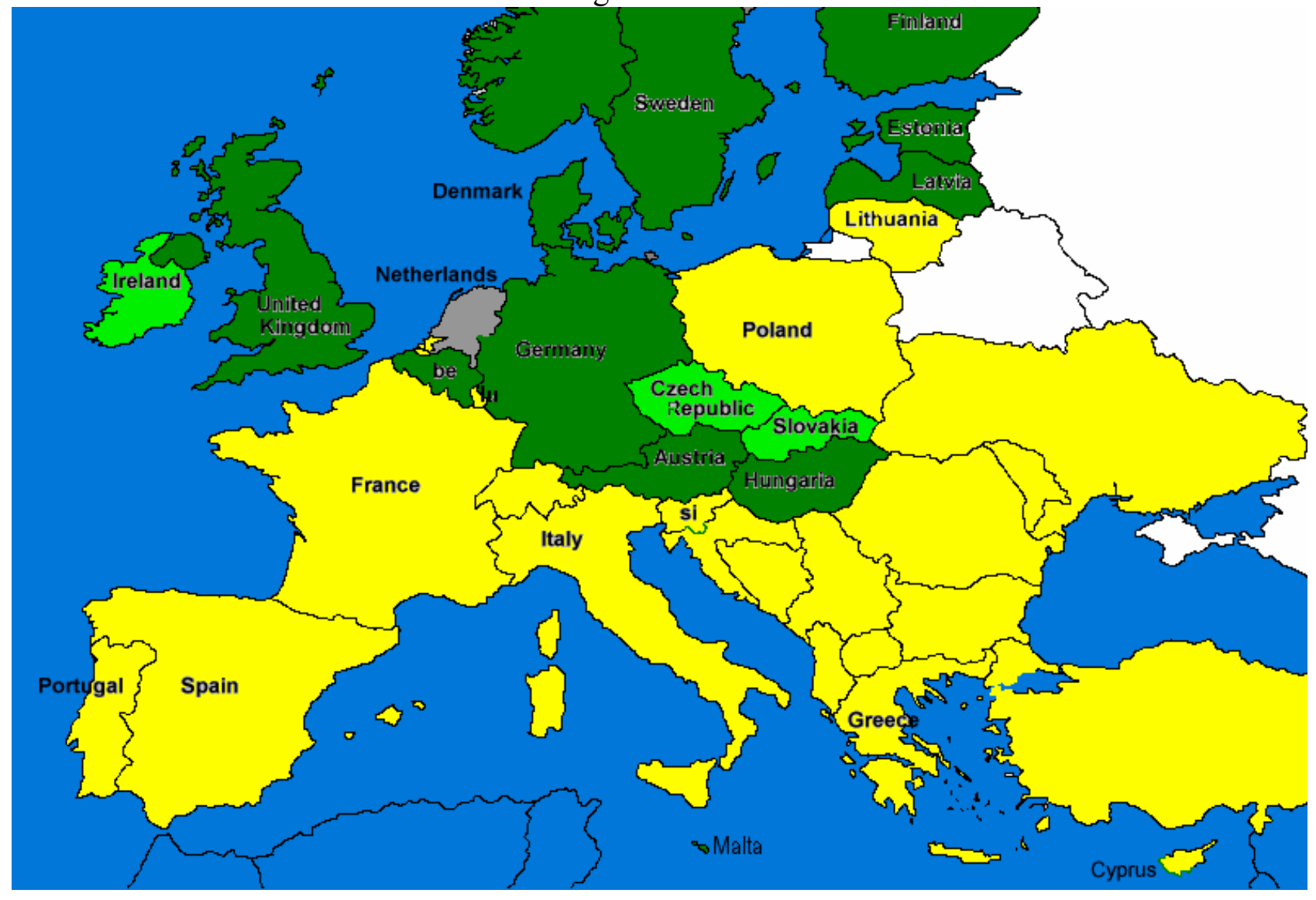


Figure 2 FSU Index distribution

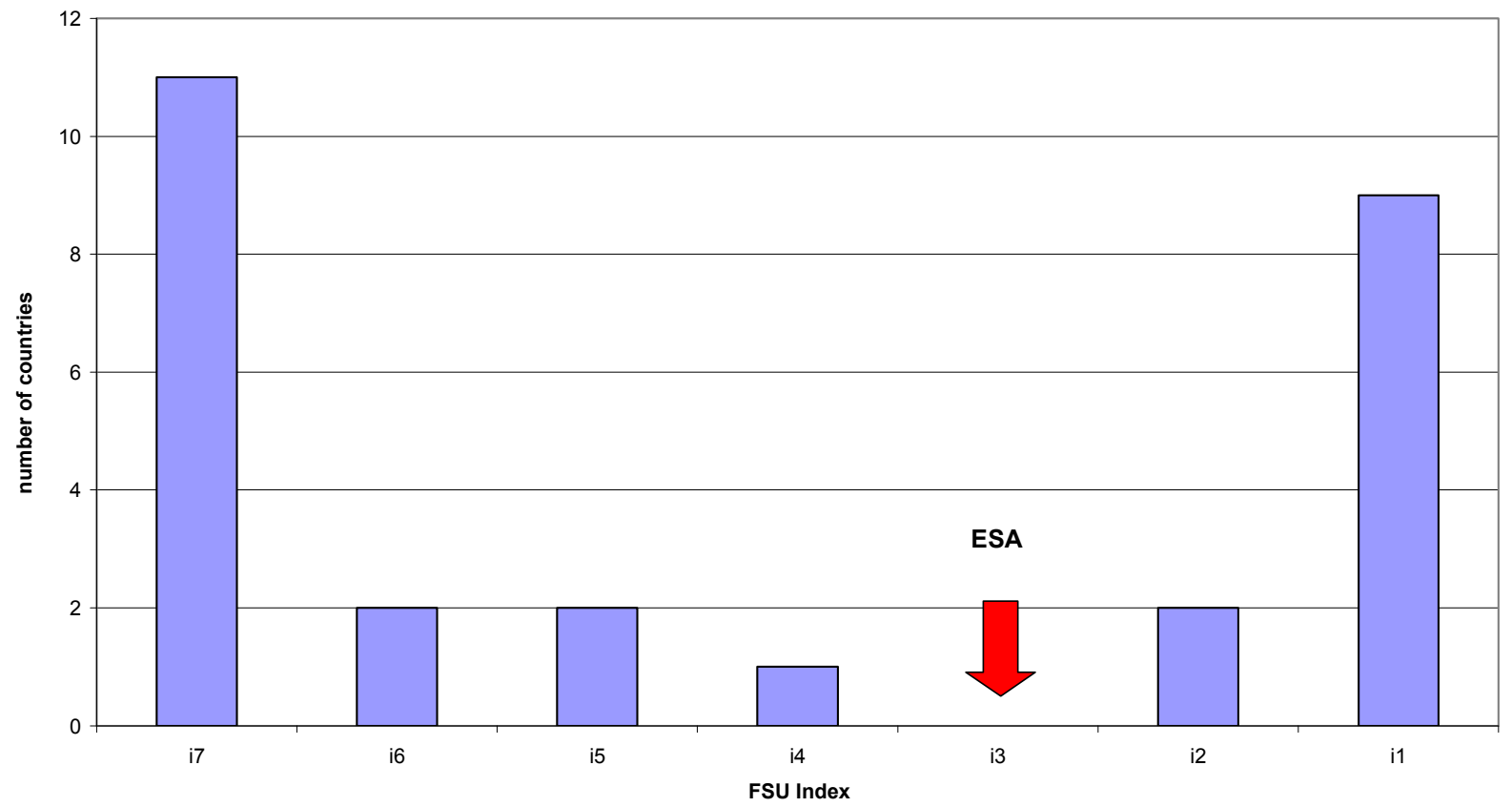

Figure 3 CBFA Index distribution

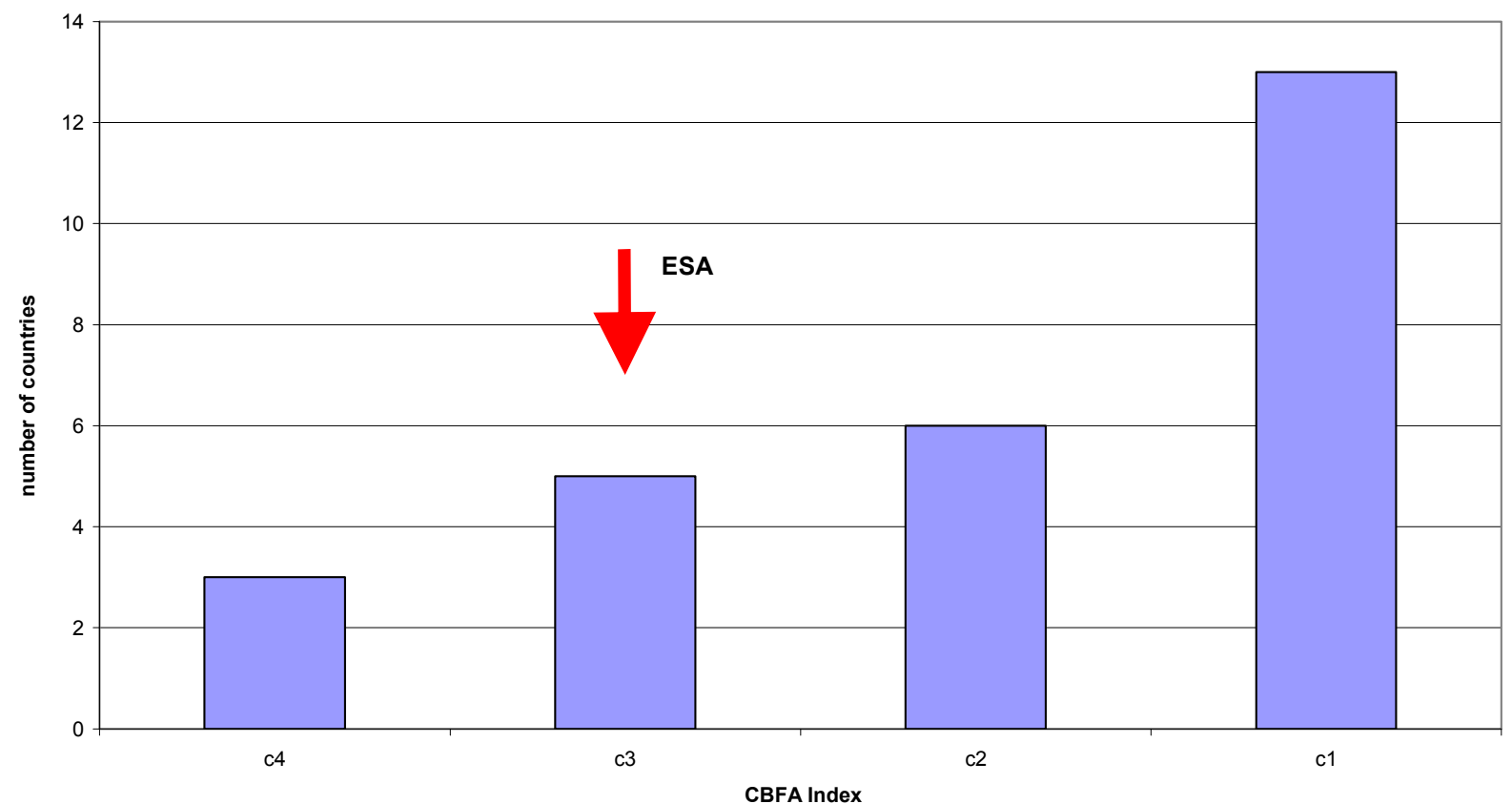


Figure 4 Financial Supervision Regimes

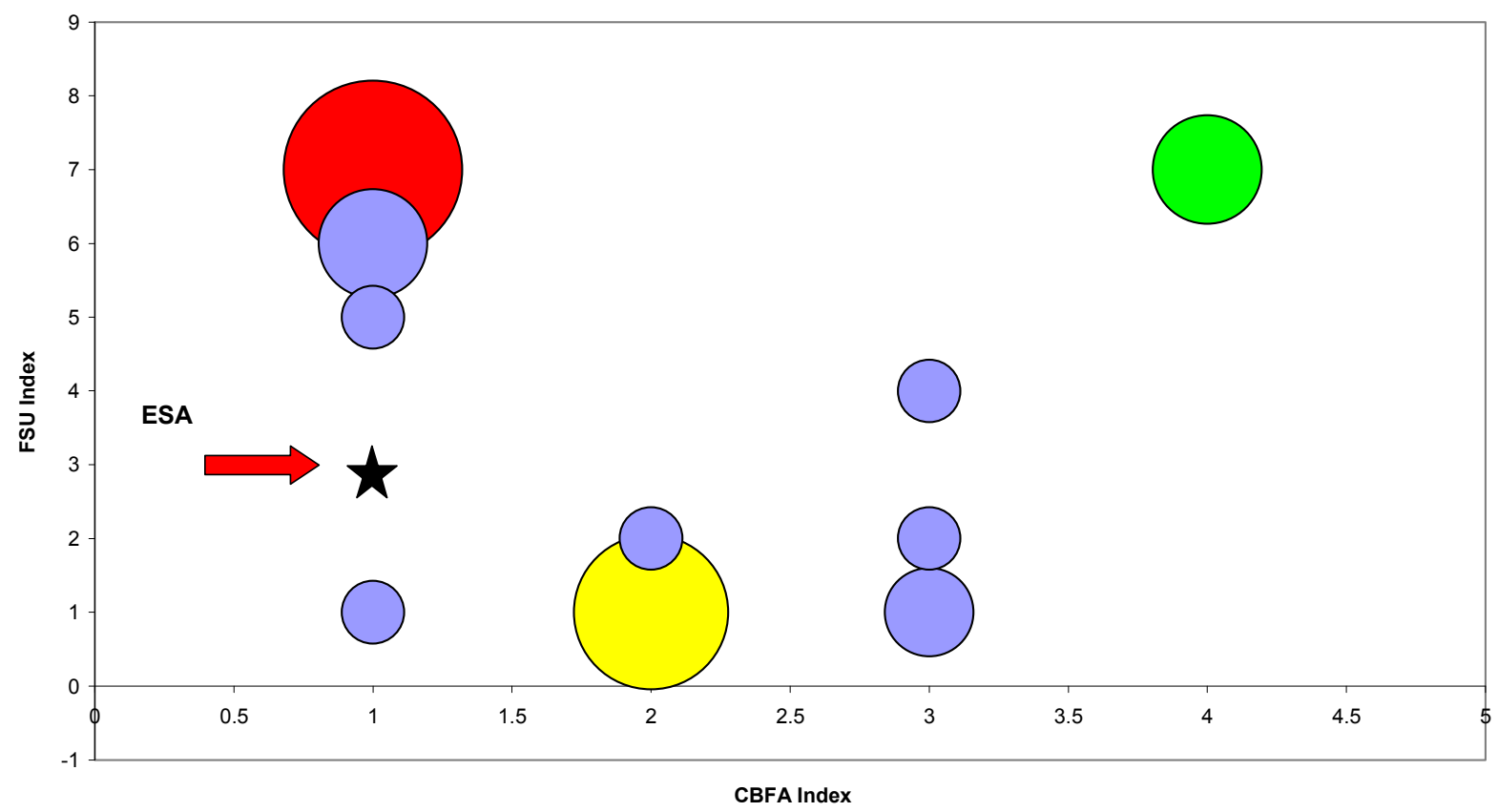

Note: The axes represent the two indices, while the diameter represents the number of countries for each regime. 
Figure 5 Institutional Independence: cross-country convergence

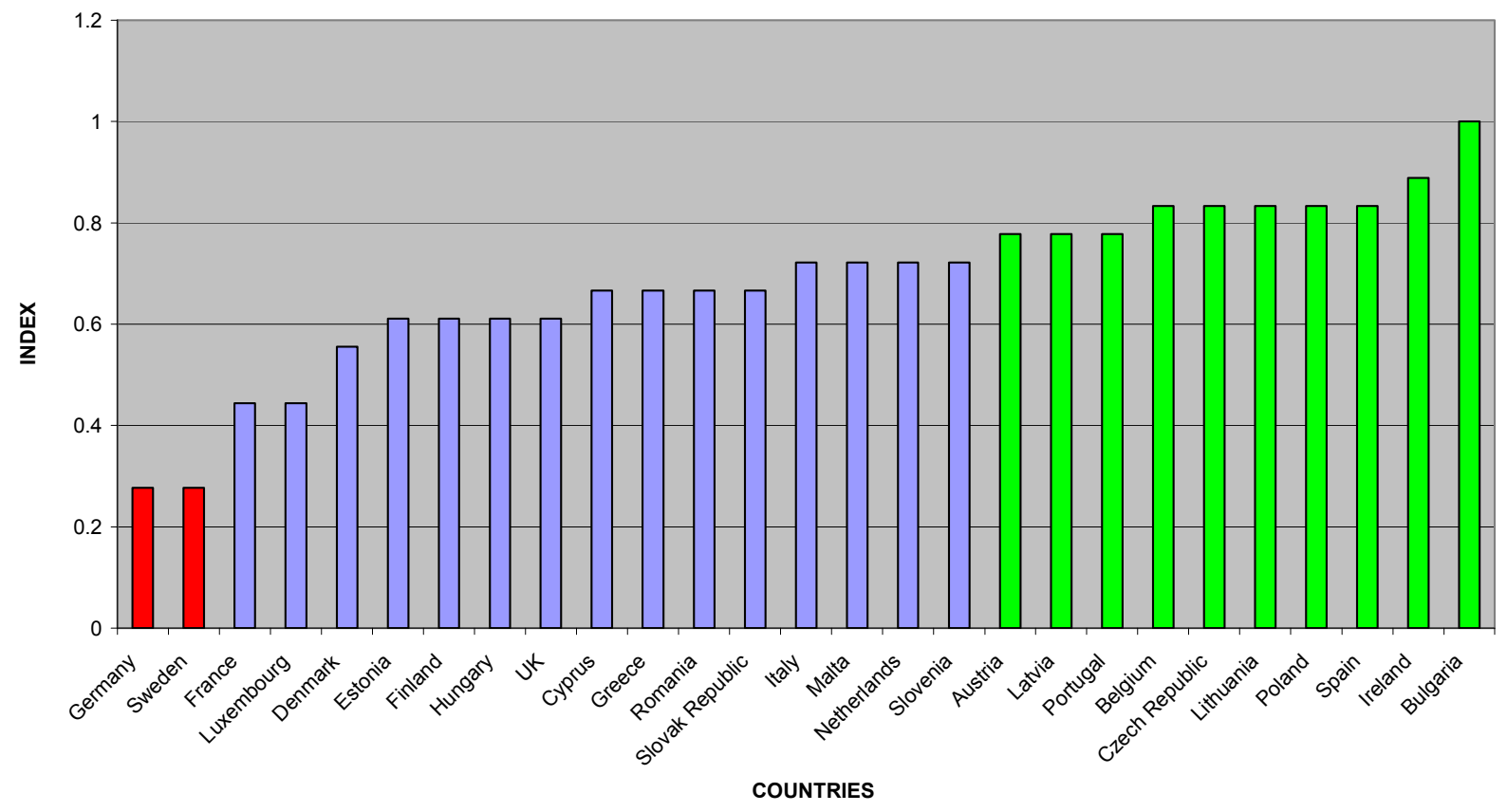

Figure 6 Regulatory \& Supervisory Independence: cross-country convergence

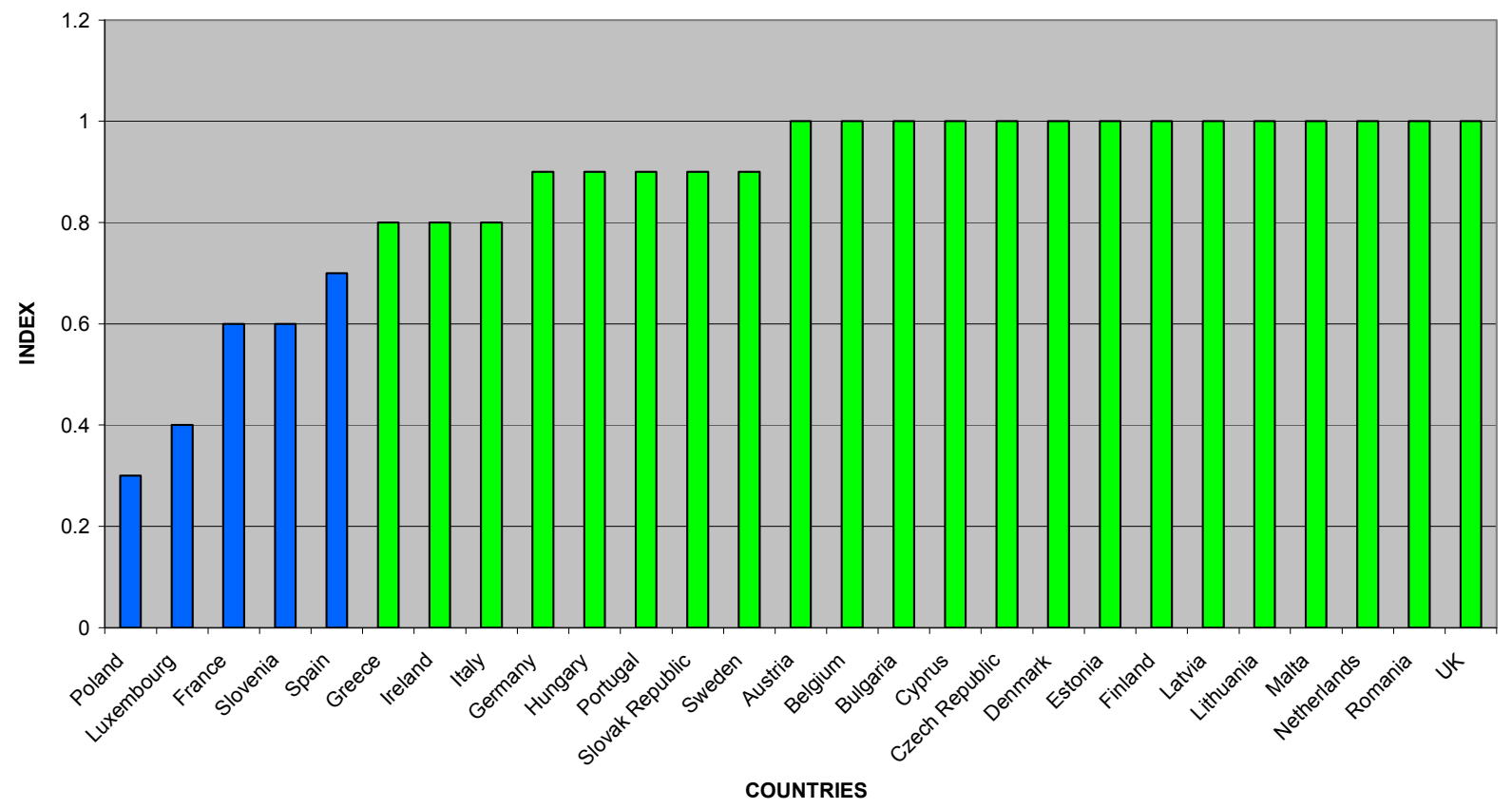


Figure 7 Budgetary independence: cross-country convergence

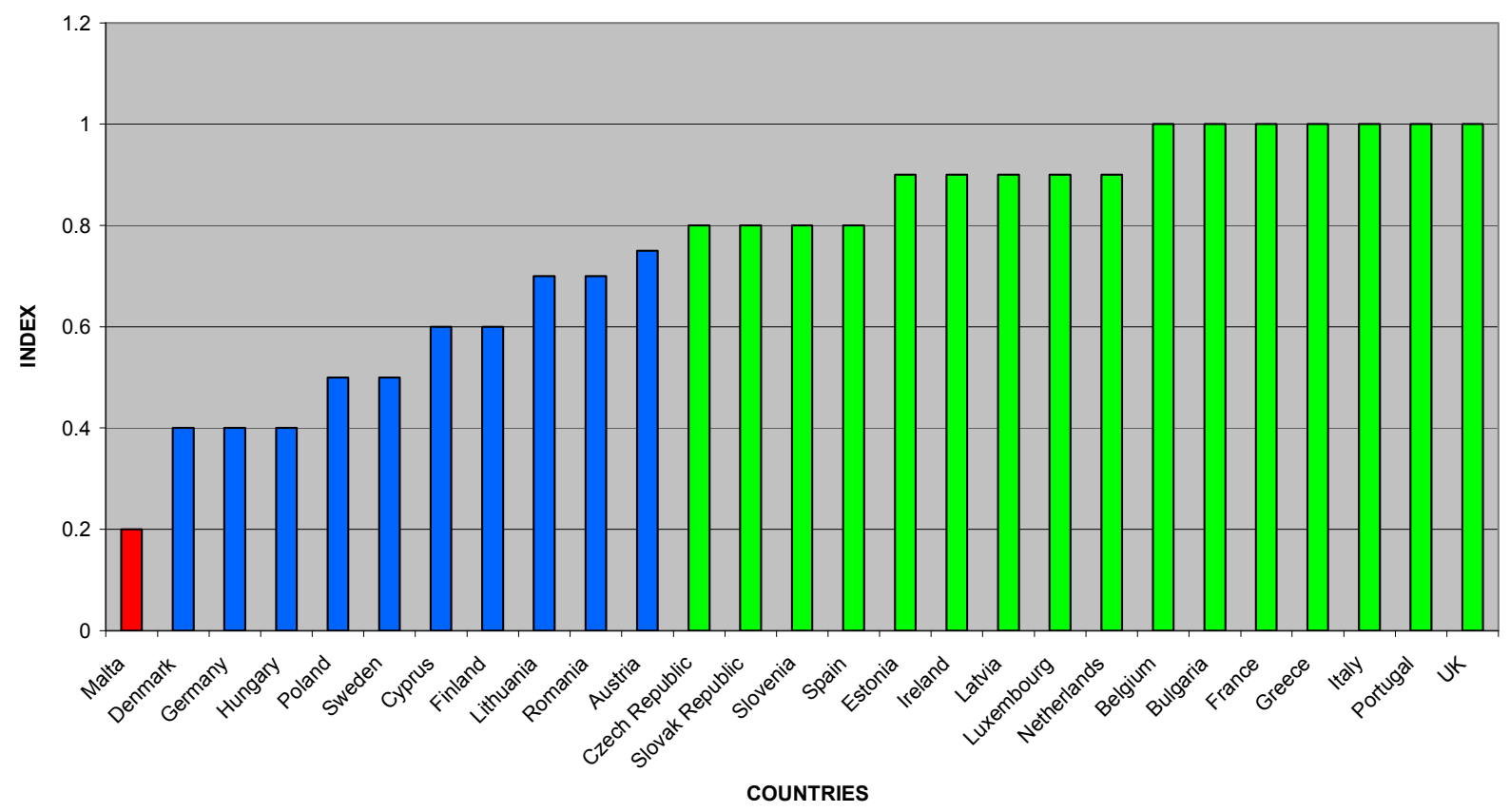

Figure 8 Political accountability: cross-country convergence

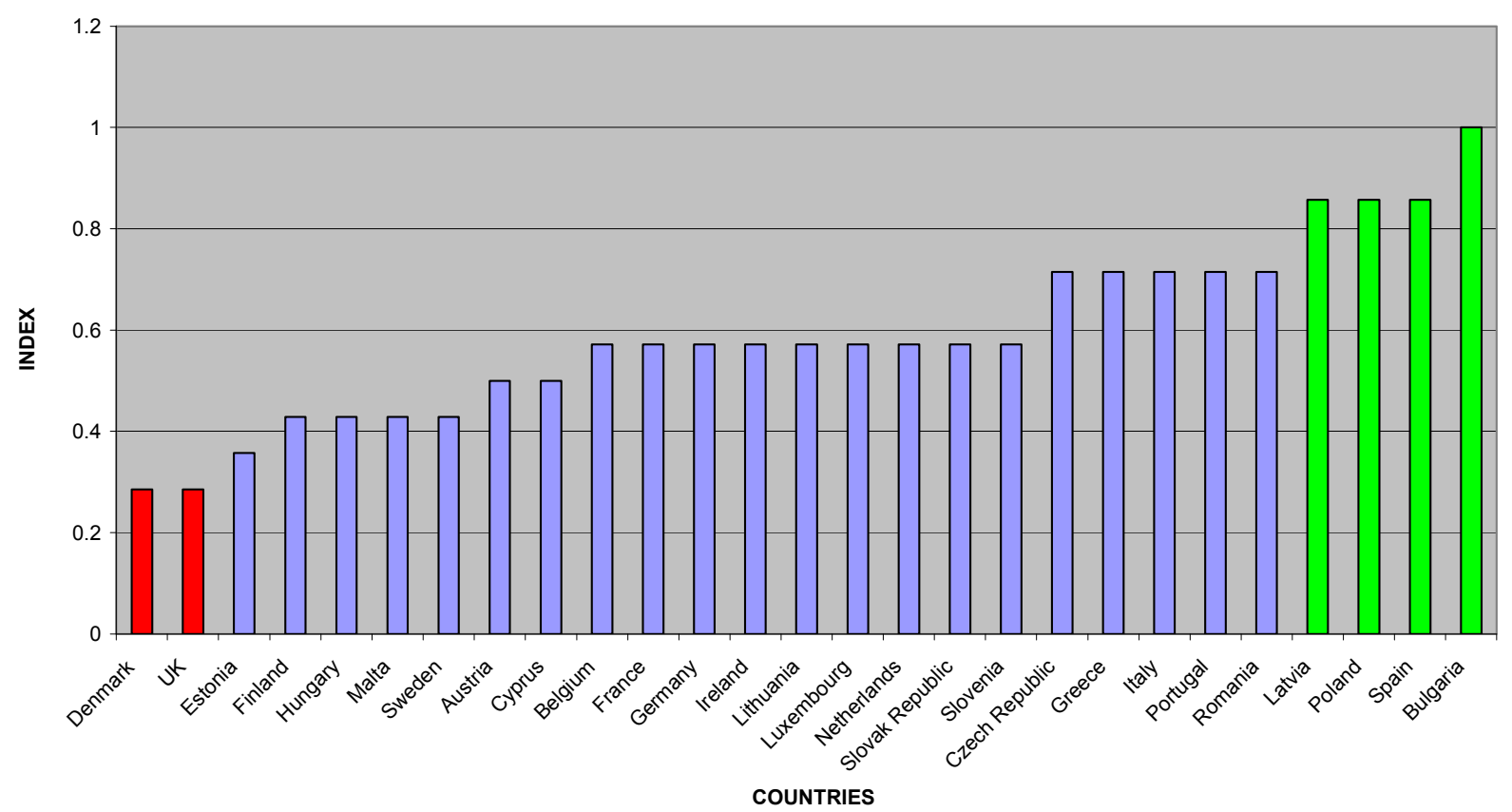


Figure 9 Judiciary accountability: cross-country convergence

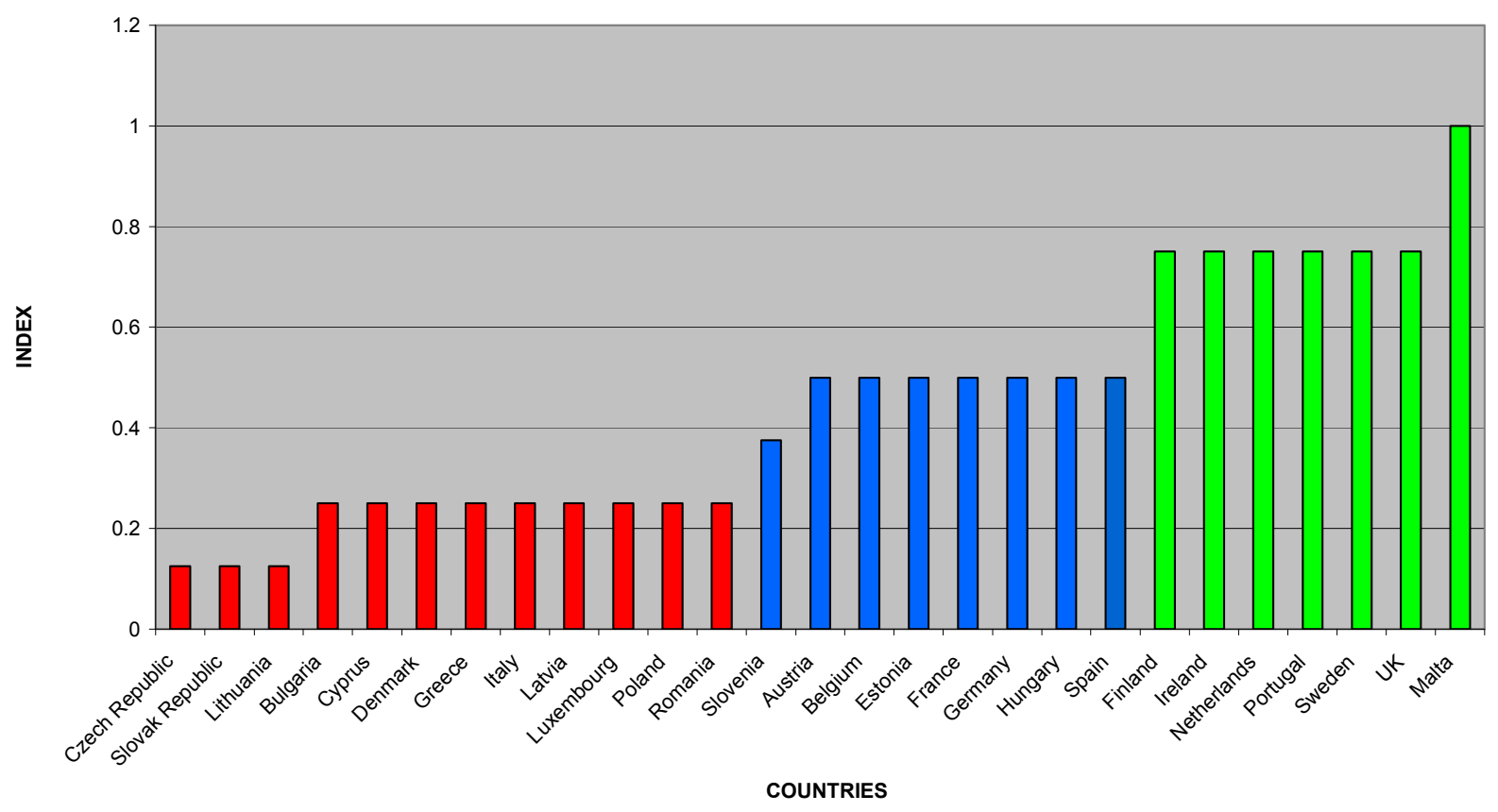

Figure 10 Transparency: cross-country convergence

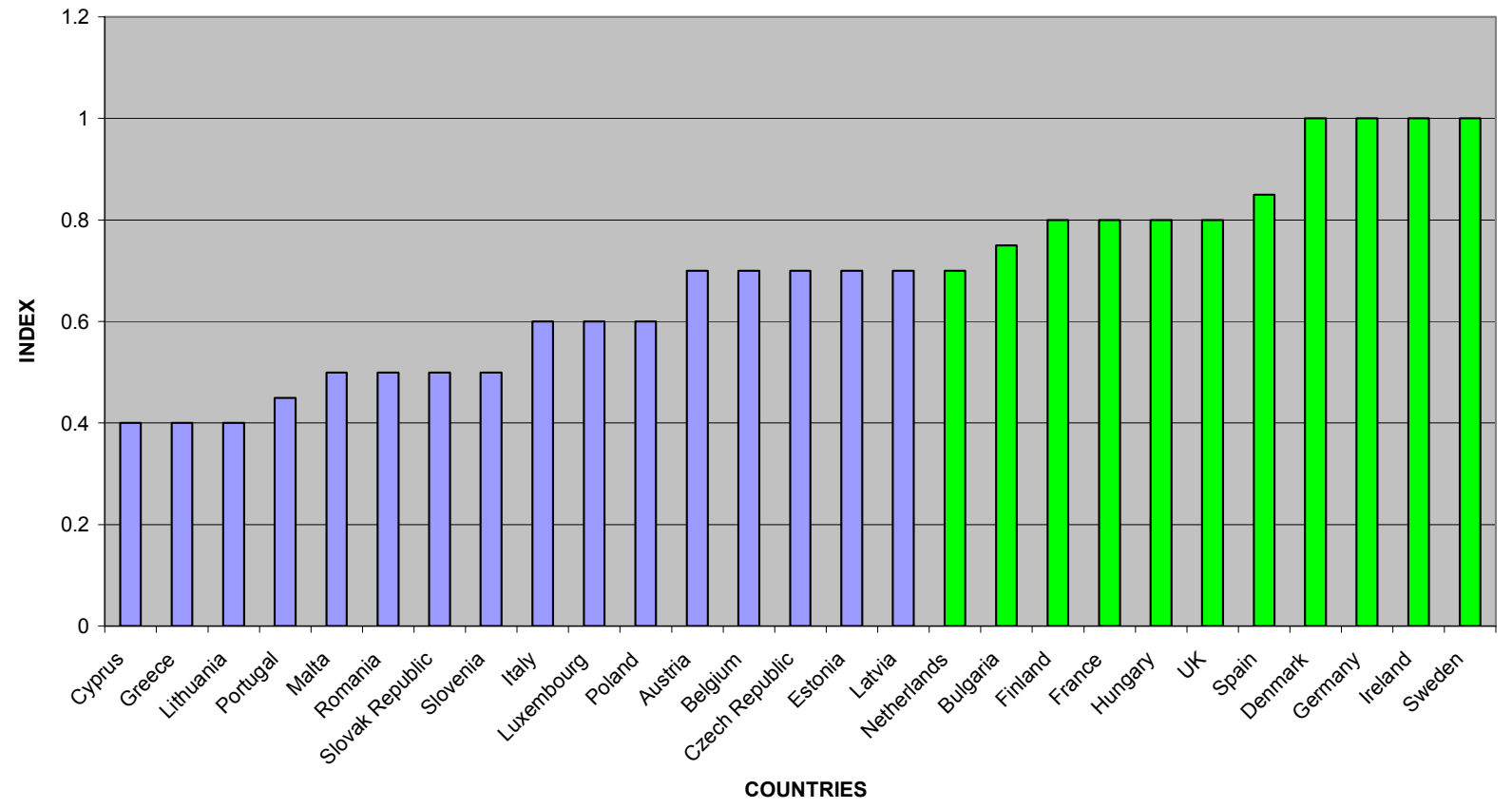


Figure 11 Total independence cross-country convergence

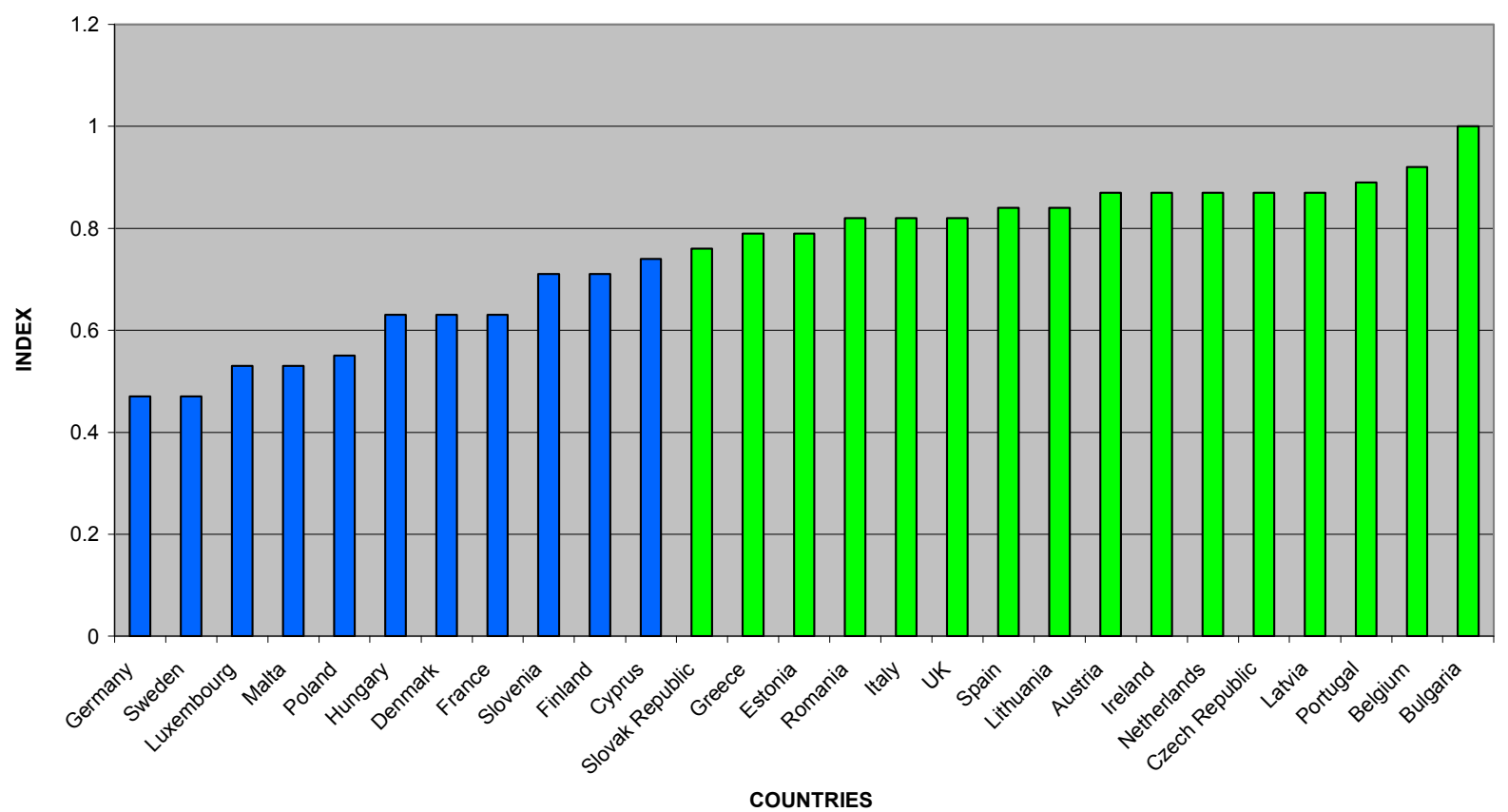

Figure 12 Overall accountability cross-country convergence

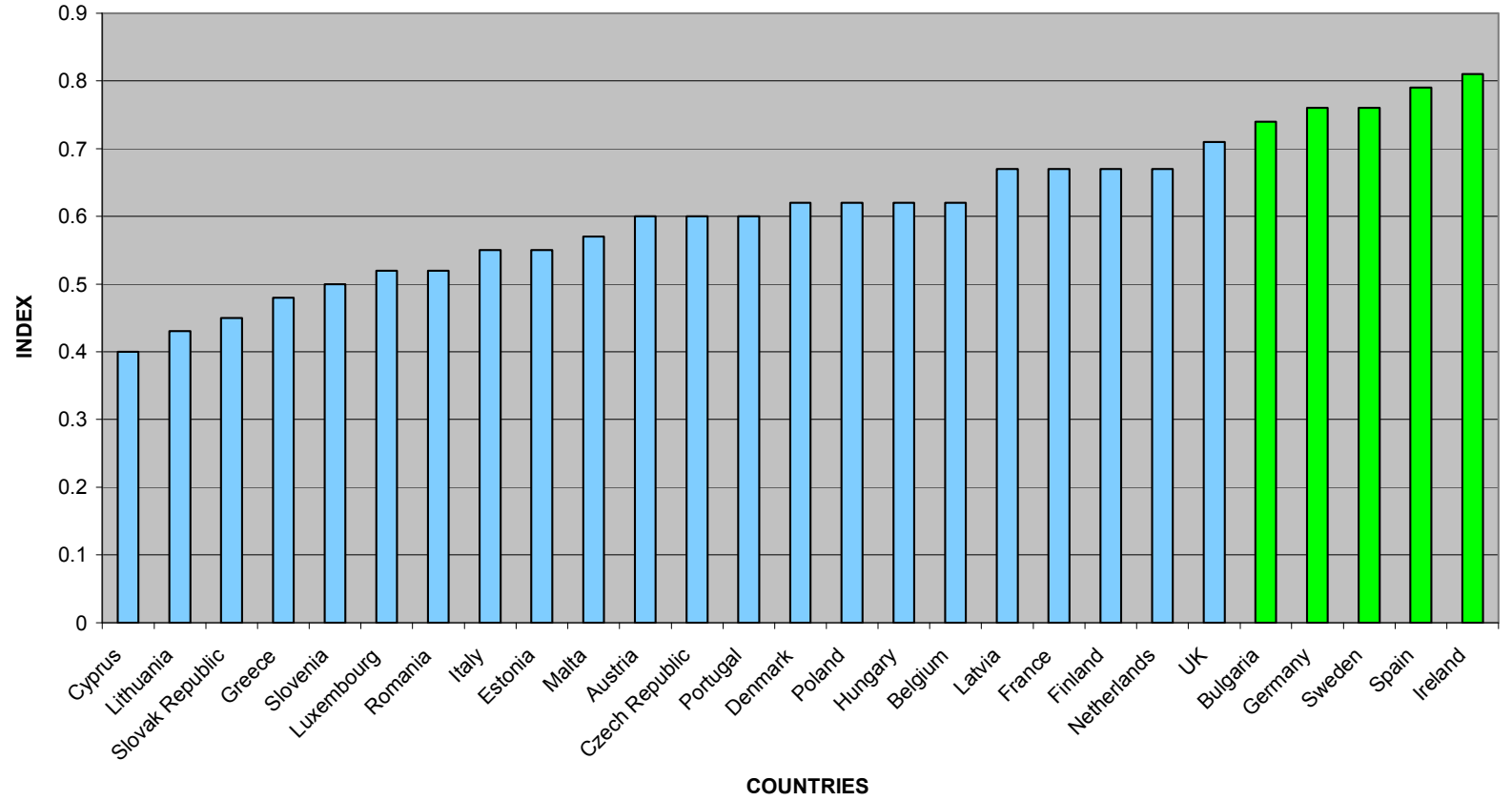


Figure 13 Independence and Accountability - Scatter plot

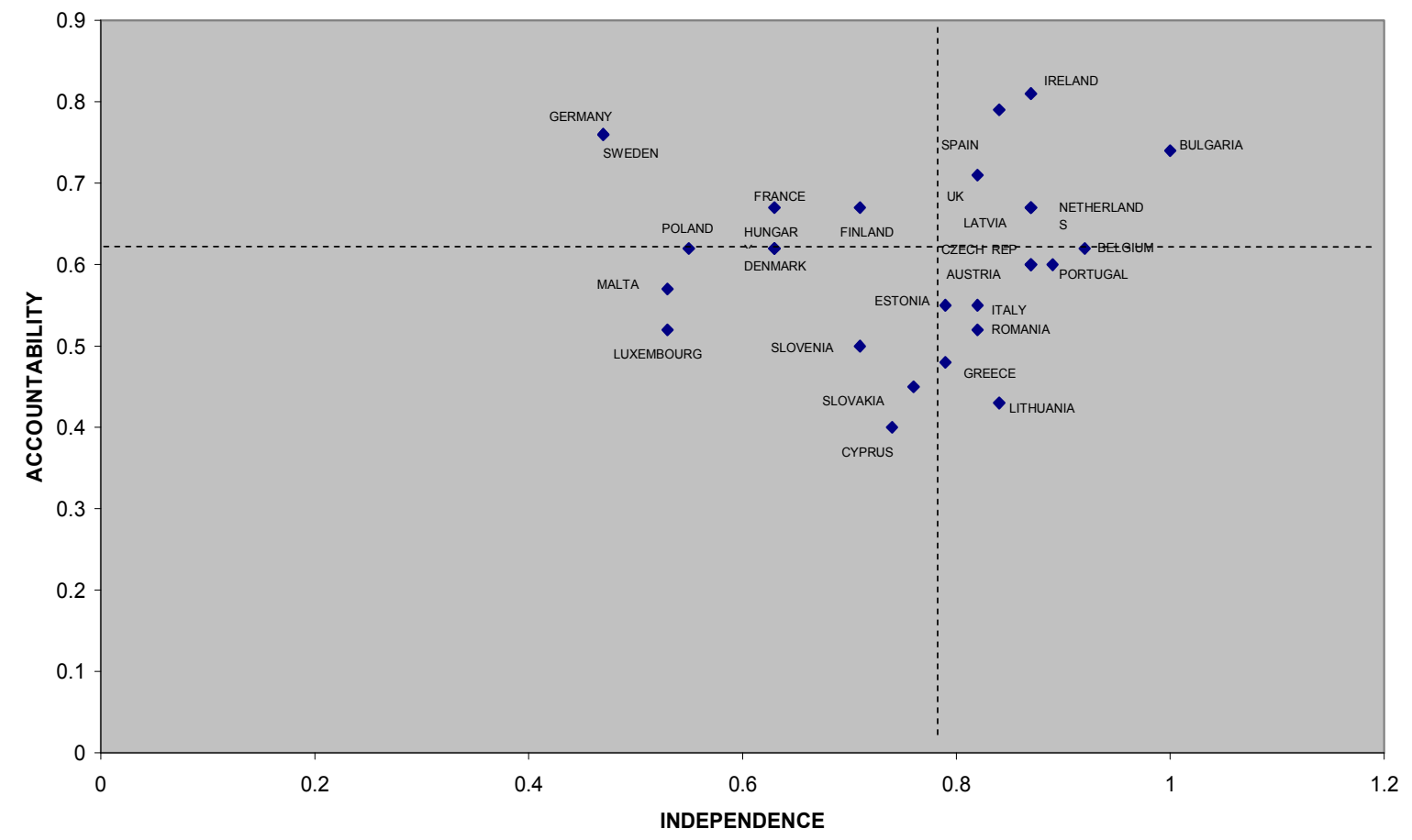


Figure 14 Independence and Accountability inside and outside the Central Bank

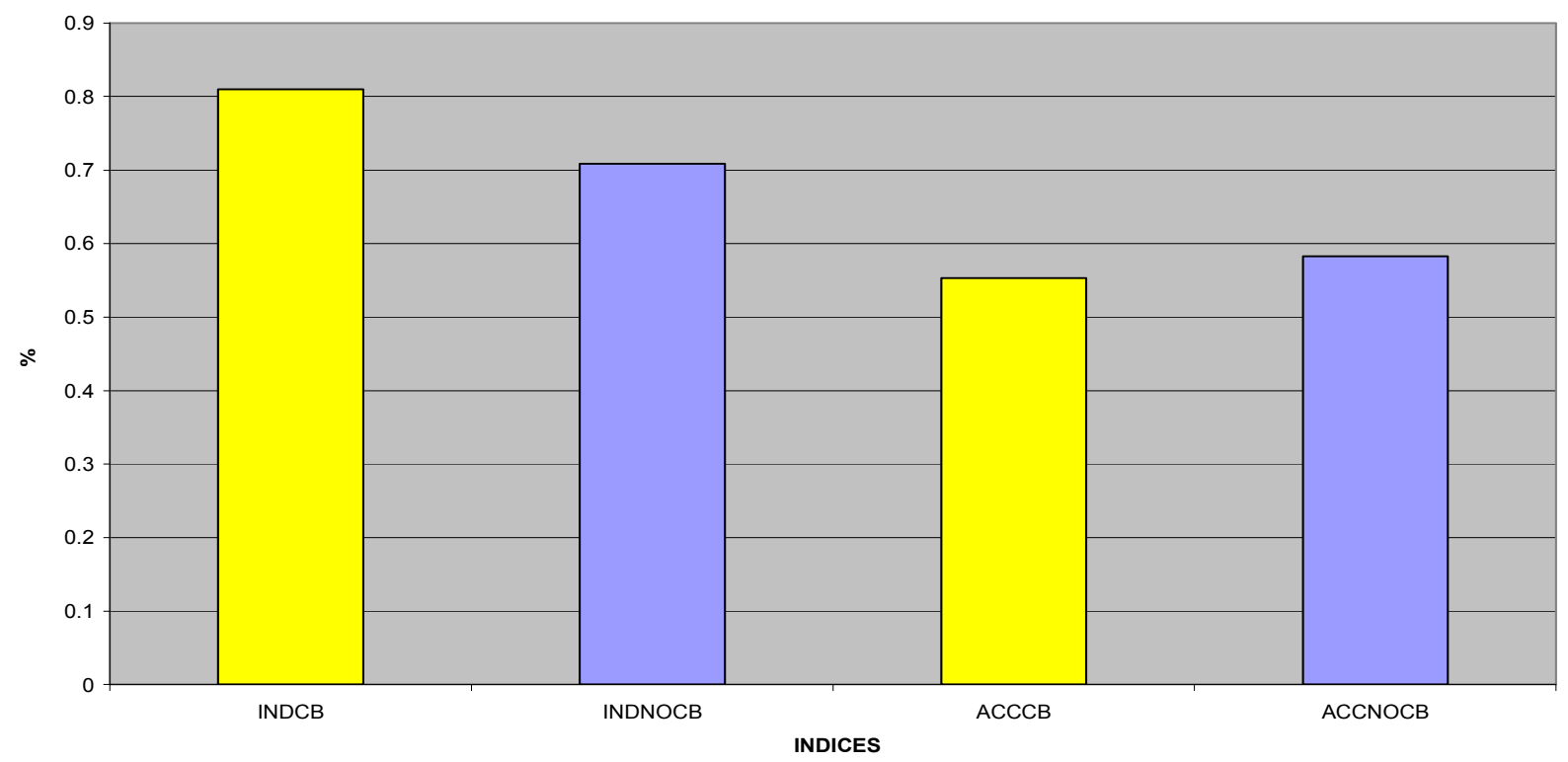

Indices: $\quad$ INDCB $=$ Independence of the supervisors located inside the central banks

INDNOCB $=$ Independence of the supervisors located outside the central banks

$\mathrm{ACCCB}=$ Accountability of the supervisors located inside the central banks

ACCNOCB $=$ Accountability of the supervisors located outside the central banks

Figure 14A: Independence Indices inside and outside the Central Bank

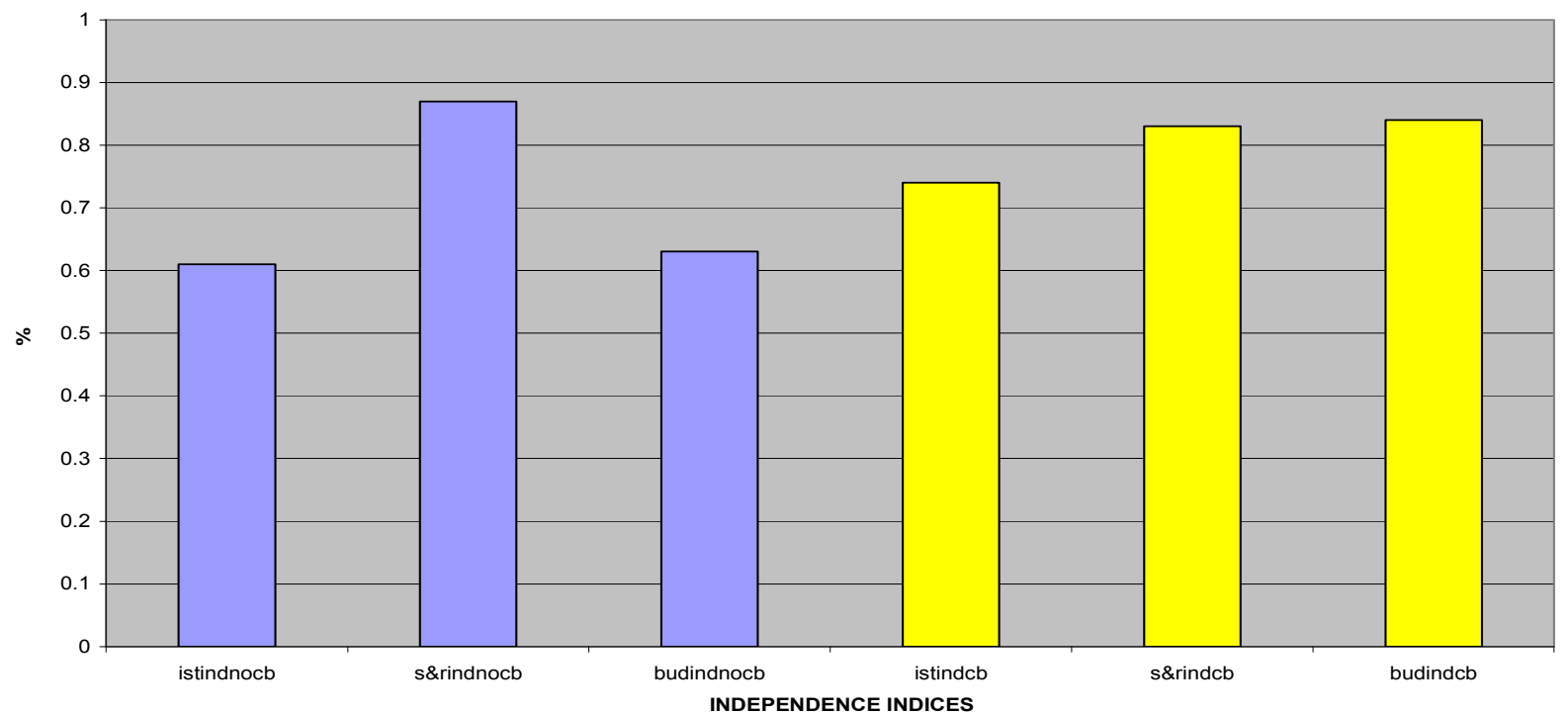

Indices: $\quad$ ISTINDCB = Institutional Independence of the supervisors located inside the central banks S\&RINDCB = Regulatory and Supervisory Independence of the supervisors located inside the central banks BUDINDCB $=$ Budgetary Independence of the supervisors located inside the central banks ISTINDNOCB = Institutional Independence of the supervisors located outside the central banks S\&RINDNOCB = Regulatory and Supervisory Independence of the supervisors located outside the central banks BUDINDNOCB = Budgetary Independence of the supervisors located outside the central banks 
Figure 14B: Accountability Indices inside and outside the Central Bank

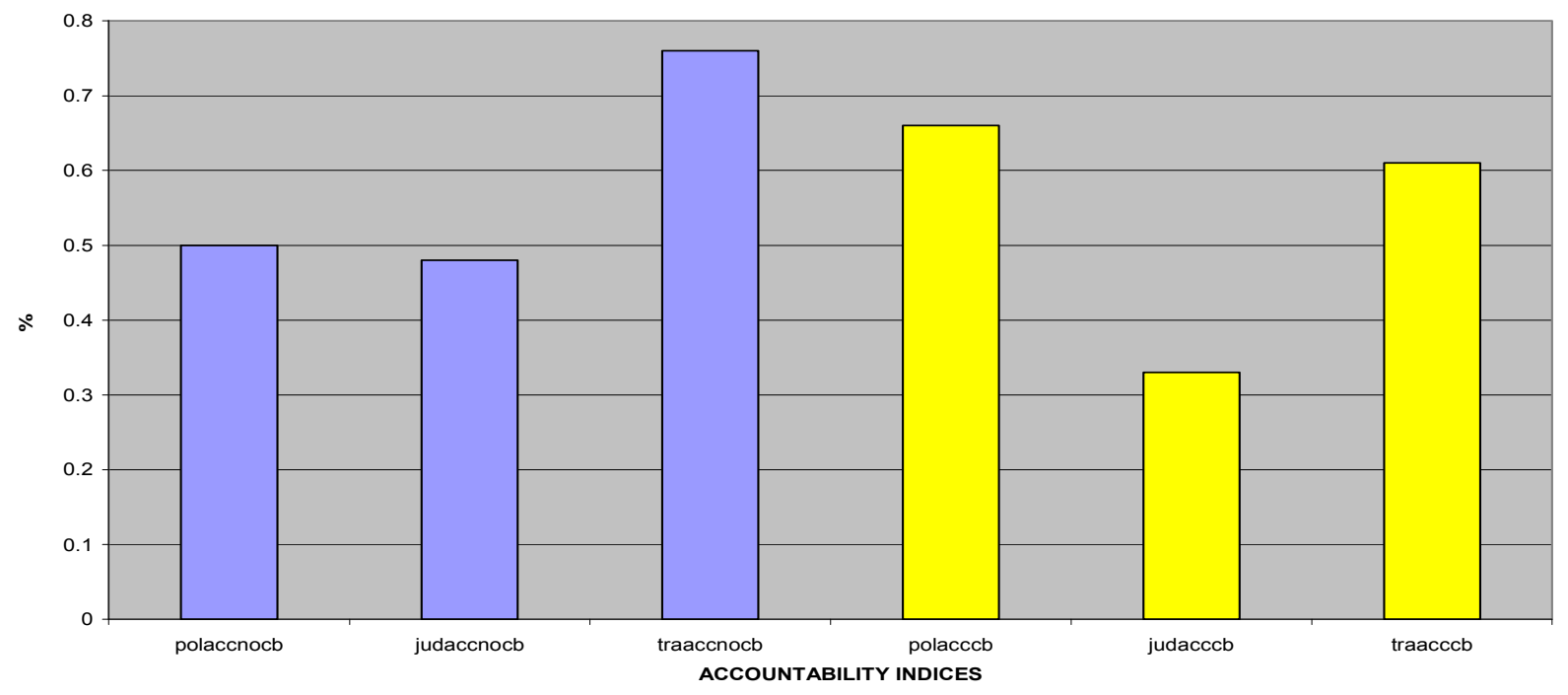

Indices: $\quad \mathrm{ACCCB}=$ Accountability of the supervisors located inside the central banks ACCNOCB $=$ Accountability of the supervisors located outside the central banks 
Table 1. The Institutional Indicators

\section{FSU INDEX}

The index was built on the following scale: $7=$ Single authority for all three sectors (total number of supervisors $=1) ; 5=$ Single authority for the banking sector and securities markets (total number of supervisors $=2$ ); $3=$ Single authority for the insurance sector and the securities markets, or for the insurance sector and the banking sector (total number of supervisors $=2$ ); $1=$ Specialized authority for each sector (total number of supervisors $=3$ ).

We assigned a value of 5 to the single supervisor for the banking sector and securities markets because of the predominant importance of banking intermediation and securities markets over insurance in every national financial industry. It also interesting to note that, in the group of integrated supervisory agency countries, there seems to be a higher degree of integration between banking and securities supervision than between banking and insurance supervision ; therefore, the degree of concentration of powers, ceteris paribus, is greater. These observations do not, however, weigh another qualitative characteristic: There are countries in which one sector is supervised by more than one authority. It is likely that the degree of concentration rises when there are two authorities in a given sector, one of which has other powers in a second sector. On the other hand, the degree of concentration falls when there are two authorities in a given sector, neither of which has other powers in a second sector. It would therefore seem advisable to include these aspects in evaluating the various national supervisory structures by modifying the index as follows: adding 1 if there is at least one sector in the country with two authorities, and one of these authorities is also responsible for at least one other sector; subtracting 1 if there is at least one sector in the country with two authorities assigned to supervision, but neither of these authorities has responsibility for another sector; 0 elsewhere.

\section{CBFA INDEX}

For each country, and given the three traditional financial sectors (banking, securities and insurance), the CBFA index is equal to: 1 if the central bank is not assigned the main responsibility for banking supervision; 2 if the central bank has the main (or sole) responsibility for banking supervision; 3 if the central bank has responsibility in any two sectors; 4 if the central bank has responsibility in all three sectors (In evaluating the role of the central bank in banking supervision, we considered the fact that, whatever the supervision regime, the central bank has responsibility in pursuing macro financial stability. Note that the countries of the Euro area are not monetary authorities. Therefore, we chose the relative role of the central bank as a rule of thumb: we assigned a greater value ( 2 instead of 1$)$ if the central bank is the sole or the main authority responsible for banking supervision.

Source: Masciandaro 2007. 
Table 2. Independence Criteria (19)

\begin{tabular}{|l|}
\hline 1. Institutional Independence \\
\hline The agency has a legal basis (law, act, ...) \\
\hline The law states that the institution is independent \\
\hline The chairman and senior executives appointed by two branches of government \\
\hline The decision-making body a board (not a single person) \\
\hline All agency staff has legal immunity for actions done in good faith \\
\hline No parliamentarians are sitting on policy board of agency \\
\hline There is no government official on the agency policy board \\
\hline The law/act does not give the minister of finance the right to intervene in policy decisions \\
made by the agency \\
\hline The law defines clear criteria for dismissal of the president of the agency \\
\hline 2. Regulatory and Supervisory Independence \\
\hline The agency can autonomously issue legally binding prudential regulations for the sector \\
\hline The agency has the sole right to issue licenses \\
\hline The agency has the sole right to withdraw licenses \\
\hline The agency has the sole right to impose sanctions on supervised institutions \\
\hline The agency has the right to enforce supervisory sanctions \\
\hline 3. Budgetary Independence \\
\hline The agency is funded through fees from the supervised entities \\
\hline The agency need not submit the budget to the government for a priori approval \\
\hline The agency has autonomy in defining salaries and salary structure of staff \\
\hline The agency can autonomously hire staff \\
\hline The agency can autonomously define the internal organizational structure \\
\hline
\end{tabular}

Source: QRT (2007) 
Table 3. Accountability Criteria (22)

\begin{tabular}{|l|}
\hline 1. Political Accountability \\
\hline The agency's mandate is defined in the enabling legislation \\
\hline With multiple mandate, the objectives are prioritized \\
\hline There is an obligation in the law to present annual report to legislative branch \\
\hline The law provides for possibility of regular hearings before committees (e.g. quarterly) \\
\hline $\begin{array}{l}\text { Accountability to the legislature is not delegated to finance minister (i.e., not the chair of the } \\
\text { agency presents the report to parliament but the minister of finance). }\end{array}$ \\
\hline There an obligation in the law to present the annual report to executive branch \\
\hline $\begin{array}{l}\text { The law provides for a possibility of regular briefing meetings with minister of finance } \\
\text { (e.g., quarterly, ...) }\end{array}$ \\
\hline The law provides for the possibility for ad hoc hearings \\
\hline 2. Accountability to the judiciary branch \\
\hline Supervised entities have the right to appeal supervisory decision to courts \\
\hline Distinct judicial processes are in place to handle these appeals \\
\hline Appeals are handled by specialized judges \\
\hline The law provides for penalties for faulty supervision \\
\hline 3. Transparency \\
\hline There is a process whereby the agency presents and discusses its budget ex post \\
\hline There is a practice of disclosure of supervisory policies and of decisions (website) \\
\hline The agency has issued a mission statement \\
\hline The annual report is available to the general public \\
\hline There is a possibility for inquiries by the general public (email, ombudsman) \\
\hline $\begin{array}{l}\text { The law provides for a consumer consultation board in the framework of regulation and } \\
\text { supervision }\end{array}$ \\
\hline $\begin{array}{l}\text { The law requires a formal ex ante consultation process with the industry about new } \\
\text { regulations }\end{array}$ \\
\hline The law requires a formal consultation process with the public at large about new regulations \\
\hline The agency has an internal audit process in place \\
\hline The agency has an external audit process in place \\
\hline
\end{tabular}

Source: QRT (2007) 


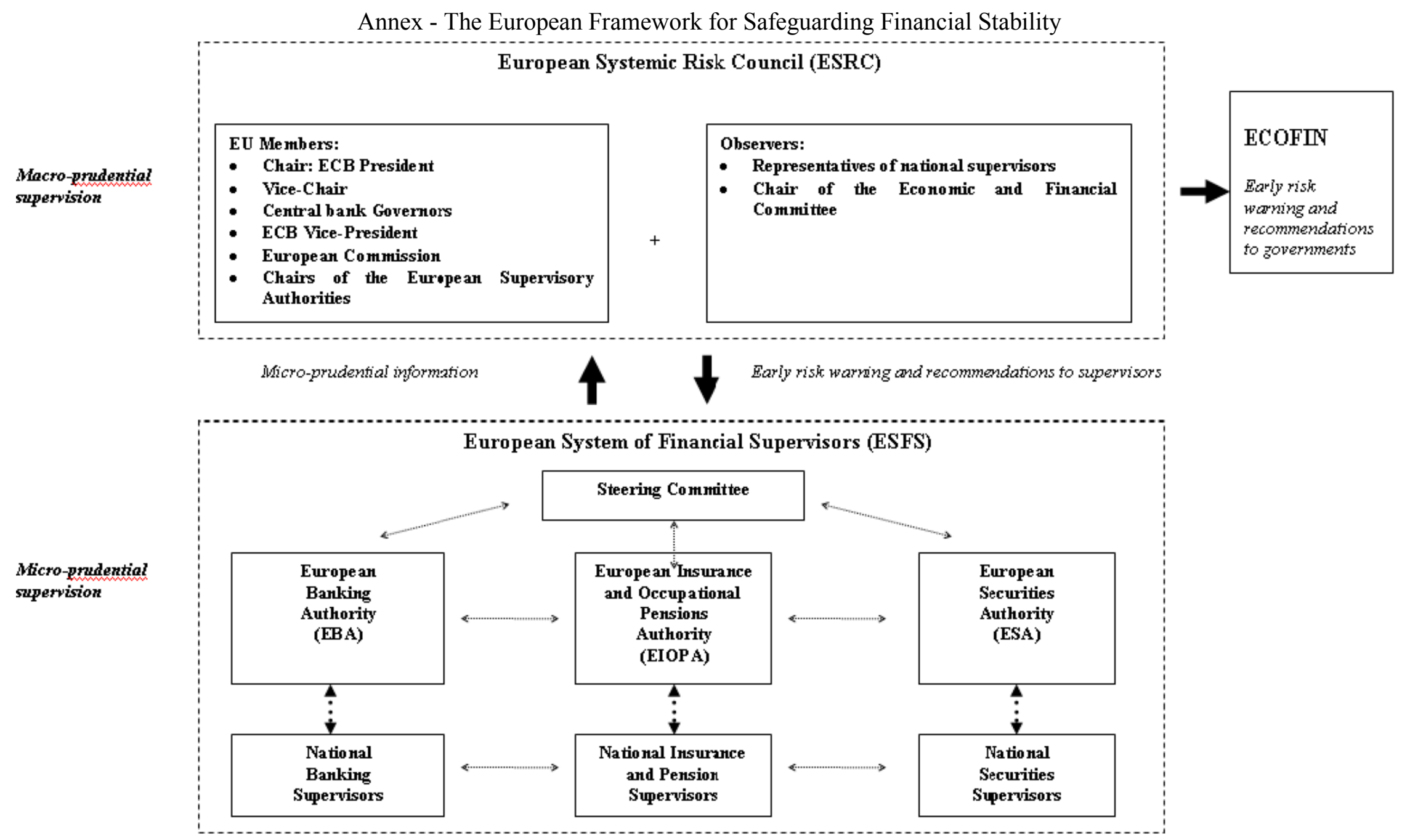

